\title{
MILITARY IDEOLOGY IN RESPONSE TO DEMOCRATIC PRESSURE DURING THE LATE SUHARTO ERA: POLITICAL AND INSTITUTIONAL CONTEXTS
}

\section{Jun Honna}

\section{Introduction ${ }^{1}$}

This article discusses the ideological adaptation of the Indonesian military (ABRI) in the face of growing democratic pressures during the late Suharto era. For the last decade, political democratization figured as a core theme of public discourse under the authoritarian New Order polity. ${ }^{2}$ Political society insisted on the need for improving human rights accountability, eliminating ABRI's praetorian political intervention, and-more generally-for broadening space for political participation. In this process

${ }^{1}$ This work is based on my doctoral field research carried out between May 1996 and May 1997 and between October and November 1998 in Jakarta. I am grateful to Dr. Harold Crouch, Professor Benedict Kerkvliet, Professor Benedict Anderson, and Grayson Lloyd for their valuable comments and criticism on an earlier version of this article. I also thank Professor Jeff Kingston and Marcus Mietzner for commenting on parts of the article.

2 On the expansion of democratic movements, see, for example, Max Lane, 'Openness,' Political Discontent and Succession in Indonesia: Political Development in Indonesia, 1989-1991 (Brisbane: Centre for the Study of Australia-Asia Relations, Griffith University, 1991); Edward Aspinall, "The Broadening Base of Political Opposition in Indonesia," in Political Oppositions in Industrialising Asia, ed. Garry Rodan (London: Routledge, 1996), pp. 215-240. 
the mass media and political figures introduced such concepts as globalization (globalisasi) and civil society (masyarakat madani) into New Order political discourse, thus identifying their own demands as historically inevitable and, once accomplished, irreversible. ${ }^{3}$ Citing the concept of globalism, generally accepted as an irresistible world trend, democratic advocates both within the regime and in society strengthened pressure for the elimination of authoritarian practices long adopted by Suharto and ABRI.

The purpose of the article is to examine the way in which ABRI has countered these democratic challenges by reshaping its ideological framework in a manner that identifies such dissent as a national "threat" - a legitimate target of security operations. The concept of globalisasi has played a decisive role in this ideological reformulation and been used to rationalize the hardline military approach to democratic movements. Our investigation focuses on the how and why of such developments. We seek the answers both in the contexts of Suharto-ABRI relations during the final decade of the New Order regime and in ABRI ideology as it has been presented and has changed, despite inertia, since the beginning of the regime. The ways in which these factors have played a role in the current transition to the post-Suharto polity is also discussed.

We first look briefly at the fundamental ideological pillar of the New Order military which supports military control of politics by referring to world and domestic conditions that make such control necessary. Then, we will discuss ABRI's organizational attempts to standardize this ideological format within the military and society; these efforts have been prominent in the decades since the late 1970 s. The next section focuses on ABRI's internal efforts since the late 1980 s to adjust the established framework of military thinking to accommodate changing international and national environment, notably the collapse of Soviet Union and the rise of social pressure for liberalization of the Suharto regime. We then examine how such ideological reshaping was colored by the shift in Suharto-ABRI relations which took place in the early 1990s, and we look at the way in which the reshaped ideological setting was translated into actual political programs during the final years of the Suharto government. The range of politico-ideological dissent that emerged in this process is investigated next, followed by my attempt to categorize three different mind-sets among the military officers which not only reflect the diversity of military thinking under the late New Order, but also may help us assess the shift in ideological balance within the military leadership during the transition to the post-Suharto polity. Throughout the article, the significances of both political and institutional factors in evolving New Order military ideology are investigated.

\footnotetext{
${ }^{3}$ Although it is hard to trace exactly when the popular usage of these terms started in Indonesia, we suspect that, as elsewhere, the end of the Cold War and the dissolution of the Soviet Union were the most significant events that generated the proliferation of these concepts emphasizing the expansion of universal values beyond national boundaries. One of the earliest discussions in Indonesia can be found in late 1990. A leading evening newspaper demanded ABRI adjust its role to face and accommodate globalization. See "Tugas ABRI dan Era Globalisasi," Suara Pembaruan, October 5, 1990. ABRI, in its own newspaper, reacted to this by insisting that the role played by ABRI to safeguard the national ideology was crucial to prevent national disintegration as happened in the Soviet Union and Eastern Europe. See "Dalam Era Globalisasi, Ideologi Tetap Diperlukan," Angkatan Bersenjata, November 12, 1990.
} 


\section{Developmentalism as the Core Ideological Basis of the New Order Military}

Since the birth of the New Order in 1966, military ideology has celebrated the pursuit of economic development which was presented as a solution to save the nation from the politico-economic catastrophes that took place under President Sukarno. Developmentalism, or modernization ideology, provided the military with a rationale that identified political stability as the precondition for development, and this logic encouraged the officers to think that the "long-term" military control of politics was justifiable since modernization was a decades-long national project. The dream of catch-up industrialization strengthened two perceptions regarding the internationaldomestic linkage. First, the perceived need for a massive infusion of foreign capital from the West during the Cold War led to the idea that political stability in everyday life-not only during emergencies-was crucial to attract foreign investments. Second, the geopolitical concern that communist penetration during the Cold War would escalate domestic subversion also convinced officers to insist on the prominent role of the defense forces in maintaining national integrity; that integrity would be achieved by military surveillance in all fields of national life. This logic rested on the assumption that long-term political stability was necessary for economic modernization. ${ }^{4}$ Having packed this development theory into its arsenal, ABRI no longer felt the need to insist that its intervention in politics was temporary or undesirable in principle. ABRI's doctrine of dual function, or dwifungsi, which was officially adopted at the beginning of the New Order, claimed for the army a "permanent" role in the defense and sociopolitical fields. This permanency was a notable characteristic in the army's definition of its own role, a characteristic derived from the developmentalist ideology, and General Suharto, as the new President, projected this perception in fortifying the New Order's legitimation.

However, this ideological framework had to be frequently reasserted and revised to insure that the military's control of politics was perpetually required since national stability was never quite fully achieved. In this ideological reproduction, the military claimed that it had the ability to maintain a stable nation, but at the same time insisted that it had not achieved complete stability. Thus, since the launching of the regime, continuous efforts were made to construct the image of national instability. After 1978 this was formally programmed and routinized within ABRI on the initiative of the National Defense Institute (Lembaga Pertahaan Nasional-Lemhannas). This military education institute established a program, the so-called National Vigilance Refresher Course (Penataran Kewaspadaan Nasional-Tarpadnas), for the indoctrination of both officers and civilians, who were taught about the widespread "potential" political threats to national stability. According to Lemhannas, this organizational effort for vigilance (kewaspadaan) indoctrination was almost completed by February 1988.5

\footnotetext{
4 For an early attempt to formulate these logics, see Ali Moertopo, Some Basic Thoughts on the Acceleration and Modernization of 25 Years' Development (Jakarta: Centre for Strategic and International Studies, 1973). Ali Moertopo was Suharto's protégé from the 1950s till the early in the 1970s. To a large extent, it was U.S.trained economists at the Army Staff and Command College (Seskoad) who indoctrinated the antiSukarno officers with the economic ideology described above. On the military's conception of economic development, see also Harold Crouch, Army and Politics in Indonesia (Ithaca: Cornell University Press, 1978), p. 273.

5 "Surat Keputusan Gubernur Lemhannas No: SKEP/07/II/1988, Tanggal 24-2-1988, Tentang Penggunaan Buku Materi Penataran Kewaspadaan Nasional dan Kegiatan Semacamnya," in Materi
} 
Assessing the content and development of this program during the period 1978-1988 helps clarify the standard threatening image ABRI used before the emergence of the social movement demanding democratic keterbukaan (openness).

\section{Tarpadnas and the Ideological Setting of Military Kewaspadaan}

Tarpadnas was a joint project of Lemhannas and the state security apparatus, the Operational Command for the Restoration of Order and Security (Kopkamtib), begun in June 1978, and it was open to ABRI members and staff of other Departments. ${ }^{6}$ It was not coincidental that the program started in June 1978, following the regime crackdown of the 1977-1978 student movement opposing Suharto's presidential reelection. ${ }^{7}$ One document prepared for the Tarpadnas in 1979 asserted that the "New Left" had taken over communist activities after the banning of the Indonesian Communist Party (PKI) in 1966 by mobilizing students and intellectuals. According to the document, the development of the New Left in the campuses had encouraged the extreme left, which used labor and land disputes to attract supporters, and the New Left had also infiltrated its members into various mass organizations and government institutions. ${ }^{8}$ Regarding the extreme right, in this case meaning Islamic fundamentalism, the document claimed that it had become fanatic and militant because the fundamentalists had no attractive propaganda to expand their organization except by using religious means. ${ }^{9}$

One year later, the Tarpadnas course in 1980 claimed that, in order to alleviate the latent danger represented by the New Left and the fundamentalists, it was urgently necessary to: reduce the increasing economic gap between the rich minority and the

Balatkom (Jakarta: Lemhannas, Mabes ABRI, 1988). In the mid-1990s, the National Defense Institute was renamed as the National Resilience Institute, but its Indonesian acronym remained unchanged.

6 The program was launched following a leadership change within the military in June 1978. Lemhannas had been headed by Lt. Gen. Sayidiman who was widely believed to be critical to Suharto's inner circle officers who had dominated ABRI's intelligence sector, such as Admiral R. Sudomo, Gen. Yoga Sugomo and Maj. Gen. Benny Murdani. In the 1978 reshuffle, which placed General Mohammad Yusuf as the new ABRI Commander, Sudomo became Kopkamtib Commander while he held concurrently the post of Deputy Commander of ABRI. Sugomo, Head of BAKIN (State Intelligence Coordination Board) who was directly responsible to the President, was posted as the Chief of Kopkamtib in October without loosing his BAKIN position. Similarly Murdani held the posts of Assistant for Intelligence in the Defense Ministry (Dephankam), Head of the Strategic Intelligence Center (Pusintelstrat) in Dephankam, Assistant for Intelligence at Kopkamtib, and since 1978 the post of Deputy Head of BAKIN. Soon after the implementation of Tarpadnas, Sayidiman was transferred to an ambassadorship (Japan) in October 1978. The new governor of Lemhannas was Lt. Gen. Sutopo Juwono, former Head of BAKIN. Thus, the Tarpadnas project reflected the ongoing dominance of intelligence sector within ABRI.

7 On nation-wide student demonstrations, see The Editors, "White Book of the 1978 Student's Struggle," Indonesia 25 (April 1978): 151-182.

8 Naskah Induk Tentang Subversi dan Penanggulangannya (Jakarta: Lemhannas, Dephankam, 1979), pp. $23-27$. The definition of the New Left is not provided in this document, but it should be noted that, as Anderson argues, people who had been with the Left before the New Order were rarely university-educated. Benedict Anderson, The Spectre of Comparisons: Nationalism, Southeast Asia and the World (New York: Verso, 1998), p. 290. Thus, perhaps ABRI identified the increasing role of universities as a new development for the Left.

${ }^{9}$ Naskah Induk Tentang Subversi dan Penanggulangannya, p. 26. 
poor majority; and minimize government manipulation of power and authority. ${ }^{10}$ With this statement, Tarpadnas acknowledged that the regime's and ABRI's own failures had been factors encouraging extremism.However, the military was not consistently in favor of easing government controls. In response to the government's decision gradually to release PKI political prisoners, Lemhannas warned that about 105 of these prisoners were still "diehards" unwilling to drop communist ideology, and named as examples the authors, Pramoedya Ananta Toer and Rivai Apin. Therefore, the paper concluded, ABRI should not relax its kewaspadaan against them. ${ }^{11}$ This alarmism was encouraged by the notion of "organization without organization" (organisasi tak terbentuk). The construction of a network of cell members without formal organization, Lemhannas insisted, had been the strategy of PKI supporters under the New Order. They had tried to undermine the national unity based on the Pancasila ideology, by attempting to infiltrate into the "floating-mass" and looking for opportunities among the labor, agrarian, student, women's, legal, and cultural movements which had emerged in the process of national development (pembangunan).12 Such a kewaspadaan perspective, which saw the latent danger of communist resurgence in the changing society, reflected the legacy of military mindsets cultivated during the 1966-7 elimination of the PKI. These attitudes were formally standardized for officer indoctrination during the first few years of the Tarpadnas program.

Once the program had been established and indoctrination routinized within ABRI, the indoctrination target was expanded in 1985 to include lower-level governmental bodies and official organizations such as the National Journalists Association (PWI), National Youth Committee (KNPI), Chamber of Commerce and Industry (Kadin), and so on. At the regional level, Kopkamtib's Inter-regional Special Operations (Laksuswil) conducted the program for the members of the regional branches of the organizations listed above and also for provincial parliamentarians. Moreover, at the lower level, Kopkamtib's Regional Special Operations (Laksusda), in cooperation with Military Resort Commands (Korem), coordinated meetings of Tarpadnas alumni to maintain the kewaspadaan indoctrination for those who had already been introduced to it. ${ }^{13}$ The extension of this indoctrination program was directed in August 1984 by General Benny Murdani who had became ABRI Commander (Pangab) and Kopkamtib Commander approximately one year earlier, in March 1983. ${ }^{14}$ As Suharto's right-hand man and as the New Order's intelligence czar,

${ }^{10}$ Pengamanan Ideologi Pancasila Terhadap Pengaruh Ideologi-Ideologi Besar di Dunia (Jakarta: Lemhannas, Dephankam, 1980), n.p.

11 Perkembangan Bahaya Laten Ex-Partai Komunis Indonesia (PKI) (Jakarta: Lemhannas, Dephankam, 1980), pp. 23-24. This document was also one of the Tarpadnas material. There is, however, no explanation of how "108" people could be a threat to national security.

12 Taktik-Taktik Komunisme (Jakarta: Lemhannas, Dephankam, 1981), pp.1-2, 5. The concept of the floatingmass was introduced in the early New Order period. It insisted that the mass of the people should express their political preferences only in general elections held every five years, so that their daily activities could be spent fully on economic development. The major advocate of this theory was Maj. Gen. Ali Moertopo.

13 For details, see Pengarahan Aster Kasum ABRI Pada Rakorter ABRI Tahun 1985 Tanggal 1 Agustus 1985 Tentang Kebijaksanaan Pembinaan Teritorial (Jakarta: Staf Teritorial, Mabes ABRI, 1985), pp. 25-32.

14 "Surat Telegram Pangkopkamtib No: STR. 61/Kopkam/1984 Tanggal 18 Agustus 1984 Tentang Pelaksanaan Tarpadnas dan Kegiatan Semacamnya." 
Murdani endeavored to expand the military's ideological surveillance in society for the further fortification of New Order political control. ${ }^{15}$ Murdani's effort was fully assisted by Maj. Gen. Soebiyakto-another intelligence officer and a close aide to Murdani-who was installed as the Lemhannas Governor two months after Murdani's promotion to Pangab. ${ }^{16}$ The kewaspadaan project which was first intended to standardize the military's (and the government's) portrait of a nation threatened by subversive forces was now transformed into ABRI's security-intelligence project, a project that aimed to shape and control political ideas in society. This move resonated perfectly with the Suharto regime's program to require all social organizations to adopt Pancasila as their sole philosophical foundation. ${ }^{17}$

The adopted kewaspadaan formula discussed above provides interesting insights into the development of New Order military ideology. Earlier, certain regime concepts, such as pembangunan and floating-mass, were presented as antithetical to the communist-influenced Old Order led by President Sukarno and therefore basically in sympathy with the New Order. By the late 1970s, however, the pembangunan and floating-mass were being emphasized as vulnerable social space that could provide the basis for underground extremist activities. This new assessment reflected the process by which ABRI's original "threat theory" had been broadened to identify a greater number of informal organizations as potentially subversive, a process that then justified military efforts to oversee the "consequences" of pembangunan after the first decade of New Order administration. Since ABRI's developmentalist ideology had rationalized the long-term military control of politics by insisting on the military's prominent role in safeguarding the ultimate national goal (i.e. pembangunan), the established kewaspadaan doctrine-that saw incorrect or contaminated pembangunan as a source of threat-enhanced the ideological justification for maintaining control.

Second, the contradictory use of New Order language in ABRI's internal study of the latent communist danger (Bahaya Laten Komunisme-Balatkom) becomes apparent wherever Pancasila is delineated as the ultimate basis of the national philosophy. In a February 1988 document which was formulated by Maj. Gen. Soebiyakto as a standard text for the subsequent Tarpadnas project, the history, thought, and activities of the PKI were described in detail, followed by the conclusion that Marxist ideologywhether it was implemented by communist or other groups-was opposed to and destructive of Pancasila society. However, this one-hundred-page paper at the same time rejected the capitalist-liberal model of society by adopting the neo-Marxist perspective on capitalism and the world-system. It was argued here that capitalism

15 About Murdani's intelligence power, see the Editors, "Current Data on the Indonesian Military Elite (Continued)," Indonesia 37 (April 1984): 149-152.

16 Significantly, Soebiyakto was former military attaché to Moscow (1977) and regarded as a "communist expert" within ABRI.

17 Since the Independence Day speech in August 1982, Suharto had hinted about this plan, and it was in 1985 that the legislation was formally adopted. This was widely perceived as Suharto's attempt to undermine the influence of political Islam. A month after Murdani's instruction above, violent riots broke out in Tanjung Priok, North Jakarta, where the hundreds of angered Muslims were shot to death by security forces. This event encouraged a growing perception among Muslim groups that Gen. Murdani, a Catholic ABRI Commander, had been operating to de-Islamize Indonesia. Regarding the series of developments, see, for example, John Bresnan, Managing Indonesia: The Modern Political Economy (New York: Columbia University Press, 1993), pp. 218-244. 
had made the rich richer and the poor poorer because the rich were the owners of capital. The paper asserted that the recent rise of multi-national corporations also resulted in the accumulation of capital in industrial countries, and this had strengthened the structural dependency of the poor countries. ${ }^{18}$ This expressed concern about both communism and capitalism is not necessarily contradictory or inconsistent, since both could undermine the ideological basis of Pancasila. ${ }^{19}$ But what should be noted is that in this document, bahaya laten komunisme was juxtaposed against neo-Marxist language by Lemhannas officers in consolidating the kewaspadaan ideology. Soebiyakto-the communist expert-seemed to know the utility of Marxist ideas.

More essentially, all Lemhannas papers examined above implied that in order to construct this Pancasila dialectic, both communism and capitalism-liberalism were "needed" as the thesis and antithesis. ABRI's standard assessment is expressed in the following comment.

When we adopted our political system, there were two mainstreams in the world, i.e. Western democracy based on individualism and the Communist regime based on class. However, they were not suitable for Indonesia where the sense of "togetherness" [kebersamaan] in society transcended both individual and class [interests]. This was the foundation of our Pancasila democratic system. ${ }^{20}$

This historical dialectic was a common perception of both ABRI and the state administrators, and it was against this background that, with or without real evidence, the Balatkom campaign gradually became a built-in ritual for the hypernationalist agenda which upheld Pancasila as the absolute value. ${ }^{21}$ In the history of New Order anti-communist thinking, this was a major development, as the ritualized warnings against subversive forces no longer required "real" threats, since the maintenance of the ritual itself became the end of organizational activity. This development enabled

\footnotetext{
18 Materi Balatkom, pp. 3-5.

19 As Weinstein's vivid study illustrated in 1976, one feeling shared among political elites since the time of the Revolution was the fear of dependence on the capitalist countries, which were defined as inherently imperialistic. Thus the officers' suspicion of capitalism was not new. See Franklin B. Weinstein, Indonesian Foreign Policy and the Dilemma of Dependence: From Sukarno to Soeharto (Ithaca: Cornell University Press, 1976).

20 Interview with Gen. (ret) Edi Sudradjat, Minister of Defense and Security, February 19, 1997.

21 Maj. Gen. Soebiyakto, Lemhannas Governor, at the opening of Tarpadnas meeting in 1988, explained that the PKI had revolted three times, so a fourth attempt might be possible. But he said it was difficult to detect. See "Mewaspadai yang Keempat," Tempo, November 5, 1988. Such a threat assessment was far from professional but well represented the ritualized nature of this kewaspadaan campaign. For a similar account which stresses the ritualization of the anti-communist campaign, see Rob Goodfellow, Api Dalam Sekam: The New Order and the Ideology of Anti-Communism (Clayton: Centre of Southeast Asian Studies, Monash University, Working Paper 95, 1995). It should also be noted that the above three revolts start with the famous 1926-27 uprising against the Dutch colonial government. This indicates that the New Order (and ABRI) identify themselves as a late reincarnation of Dutch colonial rule. For an account which suggests this point, see Benedict Anderson, "Old State, New Society: Indonesia's New Order in Comparative Historical Perspective," Journal of Asian Studies XLII (May 1983): 447-495, especially pp. $492-$ 493.
} 
ABRI to adopt Balatkom as a weapon against any societal element which did not follow this rite established by Suharto and the military. ${ }^{22}$

It was notable that the completion of Lemhannas' Balatkom study was soon followed by Suharto's decision to abolish Kopkamtib-ABRI's major tool for social control-in September 1988. In terms of military ideology, the loss of Kopkamtib was unlikely to undermine ABRI's established Balatkom thinking which had already become a standard aspect of Lemhannas courses. The Tarpadnas project was also preserved in post-Kopkamtib civil-military relations. Nevertheless, in the political context, the disbanding of Kopkamtib and the completion of Balatkom were significant indications of the growing inner-regime contestation. It was widely believed that the liquidation of Kopkamtib was primarily intended to diminish the power of Murdani who was unhappy with Suharto's choice of Lt. Gen. (ret) Sudharmono (the head of the state secretariat, or Sekneg, and the chairman of Golkar-the government party-since 1983) as vice president for 1988-1993.23 Murdani was eased out of the Pangabship by Suharto and transferred to the Department of Defense as Minister just before the presidential (and vice-presidential) elections at the MPR (People's Consultative Assembly) in March 1988. The growing disenchantment of Murdani's officers with the President was evident when Brig. Gen. Ibrahim Saleh of the ABRI fraction (F-ABRI) in the parliament (DPR) interrupted a session in the MPR by openly objecting to the nomination of Sudharmono as vice president. Although Ibrahim's unprecedented effort in the New Order was unsuccessful, ABRI's suspicion of Suharto was expressed in other places too.

Gen. Try Sutrisno, a close ally of Murdani, who had replaced the latter as Pangab, spoke to his officers just after the MPR session:

22 As if to maintain the ritual, Pangab Try Sutrisno, again at Lemhannas, explained that Balatkom's present target was "non-formal" social groups which were supposed to have links with PKI sympathizers. "Inti Amanat Pangab: Waspadai Kegiatan-Kegiatan Politik Praktis dan Kelompok Non Formal," Mimbar Kekaryaan ABRI 213 (September 1988): 7, 63. Regarding the developing anti-communism campaign, Goodfellow sees four historical phases. The first three were between 1965 and 1971, namely the physical annihilation of the PKI, the consolidation of army dominance in central politics, and the use of the campaign as a weapon of coercion against any individual or group which objected to the New Order's reorganization of Indonesian political culture. Then the fourth phase was from the late 1980s when the campaign was mainly utilized as a means of suppressing popular political expression by NGOs and students. See Goodfellow, Api Dalam Sekam, pp. 1-15. Our focus is, however, on how the military has reshaped its ideological framework to legitimize the transformation of the campaign from one target to another.

23 On the Murdani-Sudharmono antagonism, see for example, Ben Anderson, "Current Data on the Indonesian Military Elite," Indonesia 45 (April 1988): 142-145. Suharto began to find that he had become too dependent on ABRI and started to widen his power base by relying less on Murdani's ABRI in nonsecurity affairs. It was under such circumstances that Sudharmono (a retired officer, but not a man regarded as representing military community) increasingly gained the president's trust. As Sekneg, he had authority over budget allocation and allocated much of it for the strengthening of business activities of indigenous Indonesians, pribumi, with the resulting decline of budget allocations to ABRI businesses. Also, as the Golkar Chairman, Sudharmono attempted to make Golkar more independent from ABRI, by recruiting new cadres from the ranks of business who might provide financial support for Golkar, which would in turn reduce ABRI's influence in Golkar administration. ABRI leaders were hostile to such attempts by Suharmono even though they were backed by Suharto. The rise of Sudharmono is analyzed in detail in Robinson Pangaribuan, The Indonesian State Secretariat 1945-1993 (Perth: Asia Research Centre on Social, Political and Economic Change, Murdoch University, 1995). 
This time, the atmosphere [of the MPR] was different from the past cases. There was a tendency of a certain group to force its wishes in such a way as to endanger Pancasila democracy. We have to watch out for this. Recalling the MPR session which just finished, we are almost ready to conclude that ABRI's sociopolitical activities for securing the purity and consistency of Pancasila and the Constitution will be significantly difficult in the future. ${ }^{24}$

In July, Sutrisno again expressed his opinion at a meeting of officers who would be posted to non-military positions. This time, he stressed that:

Indonesia should have a healthy and dynamic Pancasila democracy in which we can nominate more than two candidates for the vice presidency and vote to decide on one of them at the MPR. This is important to improve the professionalism of all sociopolitical forces. ${ }^{25}$

These two statements by the new ABRI Commander reveal the ABRI leadership's objections to the appointment of Sudharmono by the president; they are rare examples of an ABRI Commander's open expression of dissatisfaction with Suharto's political projects. This was the first time that ABRI accepted the idea that there might be competition for the vice presidency and implicitly for the presidency. Frustrated in this way, the ABRI leadership mobilized its established kewaspadaan approach-armed with the Balatkom doctrine-against Sudharmono, who may have still intended to run for re-election as chairperson of Golkar in 1988.

Kopkamtib was mobilized to identify communist penetration in the Sudharmonoled Golkar. During the period between the March MPR session and the Golkar Election in October, there was an intensive campaign to discredit Sudharmono by claiming that he had been involved in the activities of communist organization in the early 1960s; this campaign was presumably part of Murdani's roll-back strategy against Suharto and Sudharmono. ${ }^{26}$ Suharto's September decision to abolish Kopkamtib was made under these circumstances. From the perspective of ABRI's kewaspadaan development, these events showed how the intra-military program of ideological standardization had been transformed into a tool for security surveillance in society, and how it finally became a weapon used by ABRI to challenge Suharto's political plans. It was ironic that the project, which was intended to secure the stability of Suharto's regime based on Pancasila conformity, was transformed into a military doctrine capable of

\footnotetext{
24 Try Soetrisno, "Amanat Panglima ABRI Pada Upacara Penutupan Susyawan ABRI Angkatan ke-XIV di Bandung Tanggal 14 March 1988," Mimbar Kekaryaan ABRI 208 (April 1988): 47.

25 Try Soetrisno, "Amanat Panglima ABRI Pada Acara Pertemuan Dengan Pakokar dan Karyawan ABRI Eslon-1 di Markas Besar ABRI Tanggal 15 Juli 1988," Mimbar Kekaryaan ABRI 211 (July 1988): 44.

26 A few days before the Golkar Congress in October, Kopkamtib announced that a head of a Golkar branch in West Sumatra had been involved in PKI activities, thus effectively discrediting Sudharmono's management of Golkar. This Balatkom campaign was also pursued in April by retired Lt. Gen. Sarwo Edhie Wibowo who announced his resignation from the DPR/MPR in protest against what he believed were ex-PKI figures in key governmental posts. Sarwo's action was widely seen as ABRI's attempt to tag Sudharmono as a communist. Then, for the rest of the year, the "latent danger" campaign was conducted under the name of bersih diri (clean-self) and bersih lingkungan (clean-environment) to look for those in the government (and their family members) who had any association with past PKI activities. Sudharmono finally decided not to run for the Golkar chairmanship. For details of this extraordinary campaign, see "The Latent Danger of the PKI," Tapol Bulletin 87 (June 1988); "The 'Clean-Self' and 'Clean-Environment' Witch-Hunt," Tapol Bulletin 90 (December 1988); and Goodfellow, Api Dalam Sekam, pp. 15-28.
} 
undermining inner-elite cohesion and threatening Suharto. The evolving kewaspadaan doctrine during the decade up to 1988 strongly reflected the pre-eminence of the intelligence sector within ABRI which had long been dominated by Murdani. It was remarkable, in this sense, that the completion of the Balatkom project was accompanied by the decline of Murdani's power.

However, the fall of Murdani did not mark the end of the kewaspadaan ideology within ABRI. It was ABRI's institutional inertia that had sustained the ritualized kewaspadaan thinking by repeatedly seeking new targets since the late 1980s. This activity was the generator, the life-giver, for the New Order military, which had needed to struggle continuously to maintain the legitimacy of its permanent political involvement as derived from the developmentalist ideology - as if pumping the heart to keep sending blood into the body of the living dinosaur. It was in this context that the growing democratic movements and their frequent appeals to the concept of "globalization" attracted the eyes of ABRI's doctrine managers.

\section{The Hard-line Military Thinking on Globalization}

Globalization was a concept originally popularized by the media and democratic movements in their attempts to question the legitimacy of the military's control of politics and to expand democratic space in the country's political discourse. This new weapon for advocates of democratization-including students, legal activists, NGOs, and elite critics consisting of retired generals and civilian politicians-asserted that "regime opening," or keterbukaan, was an irresistible global demand since the communist threat so often cited by ABRI was no longer relevant following the fall of the USSR and the dissolution of the Communist Bloc, which had begun in 1988. This was an unprecedented challenge to ABRI's established kewaspadaan doctrine, a challenge which threatened to cut off the military's principal resource for ideological reproduction. However, as I will discuss below, ABRI discovered-or invented-an "opportunity" in this new social trend to reassert the supremacy of kewaspadaan thinking and expand the political territory in which ABRI was free to project its ritual warnings against communism into the country's actual political program. This dynamic had nothing to do with the ongoing friction between Suharto and ABRI, but reflected ABRI's corporate interest in preserving its dominant political power rationalized by its long-standing beliefs concerning its role in the country. Institutional inertia was, therefore, at work driving the transformation of ABRI's kewaspadaan doctrine into a tool of popular repression since the late 1980s. However, it was the changing Suharto-ABRI relations that influenced the "style" of the doctrinal application. We will look at these two spiraling developments and how the globalization discourse provided ABRI with a critical opportunity to synchronize its old ideological structure with the new social discourse in such a way as to strengthen ABRI's hardline approach to popular democratic movements.

ABRI's strategic paper in 1988 is helpful for assessing the military's attitudes in the early stage of the keterbukaan movement. ABRI's basic strategic planning consisted of three pillars, i.e. long-term (twenty-five years), medium-term (five years), and shortterm (annual) assessments. To synthesize with the Balatkom study produced by Lemhannas, the Defense Department headed by Murdani formulated an annual 
strategic assessment in 1988 which was full of kewaspadaan concerns. It stated, among other things, that for the next few years in the 1990s, when international communication would become easier and wider, special vigilance would be needed to guard against the infiltration of foreign values into Indonesia-especially communism and liberalism-which might threaten the values of Pancasila and the Constitution (UUD 45), and these alien values would penetrate in places where excessive economic development had caused a widening of the social gap between the rich and the poor. ${ }^{27}$ Therefore, the internal security threat in the early 1990s, the document concluded, would be in the form of "new-style communism" (komunisme gaya baru-KGB) that might infiltrate the government and society. And kewaspadaan would be urgently required to monitor the activities of: (1) social organizations which in the past had shown hesitation in accepting Pancasila as the sole principle for all social organizations, and later accepted it in a doubtful way; (2) the fourth-generation communist group which based its tactics on the new-style communism, that is, no longer using physical means but constitutional methods, intellectual activities, government administration, and other means in order to "depoliticize ABRI"; (3) extreme groups which would try to use extra-constitutional ways-such as instigating mass riots-to further their political interests based on racial and separatist motivations; and (4) a certain group of people (pihak tertentu) who wanted liberal democracy with unlimited freedom, and whose activities spread through academic forums, discussions, and seminars as well as via the mass media. ${ }^{28}$ In order to counter these "dangers threatening Pancasila, UUD 45, national integration and development," this short-term strategic study advocated maintaining a strong kewaspadaan with the aim of eliminating any idea in society which might contradict Pancasila and the national interest. ${ }^{29}$ Though the term "globalization" was not yet used, the paper identified expanding international relations as the key factor that would activate these threats.

ABRI's intermediate-term strategy for 1989-1993 paid special attention to security management during the 1992 election and the presidential election at the general session of the MPR in 1993. The policy guideline for the territorial apparatus stated that certain groups in Indonesia tried to use emotional issues to stir up disputes, such as land disputes, and that they encouraged demonstrations and riots in response to racial-religious issues so as to further their political interests in the general elections and the presidential election. ${ }^{30}$ In response to these threats, the territorial commands

\footnotetext{
27 Analisa Lingkungan Strategi Pertahanan Keamanan Negara 1988-1989 (Jakarta: Direktorat Jenderal, Perencanaan Umum dan Penganggaran, Dephankam, 1988), pp. 126-127.

${ }^{28}$ Ibid., pp. 128-130. Emphasis added. The second assessment here showed how ABRI had perceived public criticism of dwifungsi-namely criticism of ABRI's political repressive acts, its support for Golkar during the elections, its extensive control of seats in the parliament and civilian posts in the governmentas an attempt to depoliticize ABRI. It interpreted such criticism as opposed to national stability and political life based on Pancasila, thus designating these critics as proper subjects of security operations. Also reflecting the third assessment, the government and ABRI decided to impose on Aceh in 1989 the status of a Military Operation Area (Daerah Operasi Militer-DOM) in order to intensify the security operations against the separatist movements in that region. The two other areas which also had this status were Irian Jaya and East Timor.

${ }^{29}$ Ibid., p. 66. Emphasis added.

30 Pokok-Pokok Kebijaksanaan Pembinaan Teritorial Tahun 1989-1993 [No: Kep/04/VII/1990] (Jakarta: Mabes ABRI, 1990), pp.10-11.
} 
were instructed to sustain the kewaspadaan effort, scrutinize the activities of former political prisoners, manage political conditions for the election and the MPR session, neutralize the negative impact of economic development and new advanced technology, and combat any effort by certain groups to manipulate religion for political gain. ${ }^{31}$ This guidance showed that the concept of "vigilance against certain groups" was not only a tool of ideological indoctrination but a core part of ABRI's territorial operations now put into practice.

However, ABRI's conduct of security during the election and its handling of the MPR gave legitimacy to those who demanded that the tight security practices of previous years be relaxed. ${ }^{32}$ ABRI responded to this demand on the twenty-eighth anniversary of the failed "communist" coup of 1965 (G30S/PKI) in September 1993, when Lemhannas published a thick document about kewaspadaan and Balatkom under the instruction of the Lemhannas Governor, Maj. Gen. Hartono. ${ }^{33}$ One of Hartono's contributions to ABRI's kewaspadaan discourse was his argument that communist tactics were no longer the monopoly of communists but had now been "borrowed and adapted" by "certain groups for certain political interests." 34 By distinguishing the method from the ideology, Hartono argued that non-communists also utilized communist methods in their attempts to topple the government. Needless to say, this interpretation was quite useful when condemning popular political movements in which ABRI couldn't find even a scent of communist ideology. Also, since the term "certain group" was open-ended, any political trouble-maker so identified by ABRI could be brought into this category if necessary. To support this approach, the document developed an argument which can be summarized as follows.

It first countered the claim that the communist threat was just an illusion since the end of the Cold War and the collapse of the Soviet Union. The document explained that with the end of the Cold War the world entered an era of globalization and freeflowing information which had a great impact on Indonesia's development because the boundary between the domestic and international systems was rapidly becoming

\footnotetext{
31 Ibid., pp. 20-23.

32 We discuss the events in the 1993 MPR in the next section.

33 The document is Sekitar Padnas, Bahaya Latent \& Tapol G.30.S./PKI (Jakarta: Lemhannas, Dephankam, 1993). Hartono had been appointed to this position since February 1993 . He was a devout Muslim who earned credit during his term as the Commander of East Java by arranging security for the launching of the Suharto-sponsored Indonesian Association of Muslim Intellectuals (ICMI) in Malang (East Java) in December 1990. This body was chaired by Suharto's civilian protégé, Professor B. J. Habibie (Minister of Research and Technology), and it was widely seen as Suharto's tactical incorporation of Islam for the broadening of his political power base. This move resonated with Suharto's alienation from Murdanilinked officers in ABRI, and Hartono was viewed in ICMI circles as an ICMI activist in uniform who had emerged in this process. Officers who had links with Murdani and Try Sutrisno were, however, suspicious about Suharto's rapprochement with Islam, since it might undermine the established political practice based on the secular Pancasilaism. ABRI Commander Try Sutrisno is said to have advised Suharto to refuse approval to establish ICMI. See Robert Hefner, "Islam, State, and Civil Society: ICMI and the Struggle for the Indonesian Middle Class," Indonesia 56 (October 1993): 24. About anti-ICMI opinions among Murdani's allies, see Douglas E. Ramage, Politics in Indonesia: Democracy, Islam and the Ideology of Tolerance (New York: Routledge, 1995), pp. 138-144.

34 Sekitar Padnas, Bahaya Latent E Tapol G.30.S./PKI, p. III. Emphasis added. As a logical consequence, Hartono insisted that such a new trend became the target of kewaspadaan in ideological, political, economic, sociocultural, and defense fields.
} 
meaningless. This phenomenon introduced a new spectrum of threats into every field of national life. In politics, globalism encouraged the penetration of capitalism, liberal thought, and other foreign ideologies into Indonesia which contradicted the Pancasila philosophy and jeopardized the Indonesian defense system based on the Total People's Defense (Hankamrata). ${ }^{35}$ In the economic field, the free-market economy had an impact on Indonesia's Pancasila economy based on kemitraan (partnership), while in religious life, globalization facilitated the influx of foreign values which would disturb religious groups. The document thus concluded that these threats would damage social harmony and national resilience (Ketahanan Nasional). ${ }^{36}$ It was against these perceived challenges that the kewaspadaan campaign had to be conducted and, significantly, Lemhannas repeatedly emphasized the campaign's synchronization with Ketahanan Nasional as the total defense policy. This was the argument ABRI invented when it realized that the umbrella of Ketahanan Nasional-an indisputable national concept-could be useful to rejuvenate the ritual of Balatkom and kewaspadaan which was, to a large extent, a historical legacy. By attaching the kewaspadaan project to Ketahanan Nasional, ABRI found a new way of rationalizing the project which had faced the decline of its historical legitimacy after twenty-eight years of regime stability.

Hartono, who was promoted to the Armed Forces Chief of Social and Political Staff (Kassospol) with the rank of lieutenant general in January 1994, expressed his views on the national threat in a more systematic way in a Lemhannas journal. ${ }^{37}$ This time, he stressed the threat posed by capitalism-liberalism which accompanied globalism, rather than emphasizing communism as he had done previously. According to Hartono, the rapid development of science and technology (IPTEK) in the era of globalization greatly influenced the ideological-political-economic-socioculturalmilitary (ipoleksosbudmil) areas of national life, so it was the task of "professional" ABRI officers to anticipate its negative influences. The idea that the global change was a threat to the nation was underlined, as he argued that:

... the bipolar international system under the Cold War had ended and been replaced by a tendency to form a uni-polar system under Western capitalismliberalism. [As a result], the global economy speeded up the penetration of foreign culture through advanced information/communication technology and made Westerners think that their cultural values were universal. They then started to pressure other countries over the issues of human rights and environmental protection. ${ }^{38}$

\footnotetext{
35 Despite such a worry about capitalism in the early 1990s, it was a reality that the regime had invited massive foreign investment by Western capitalists since the mid-1960s.

${ }^{36}$ Above explanations are from Sekitar Padnas, Bahaya Latent \& Tapol G.30.S./PKI, pp. V, 1-10. Ketahanan Nasional is a national doctrine which encompasses security-political-social-economic-ideological fortifications to maintain Indonesia's autonomy in international society. This concept was officially formulated in the 1978 Broad Outlines of State Policy (GBHN).

${ }^{37}$ R. Hartono (Letjen TNI), “Pengaruh Perkembangan IPTEK Terhadap Aktualisasi Pengabdian Generasi Penerus ABRI," Majalah Ketahanan Nasional 60 (1994): 43-56. As seen in the next section, Hartono's appointment to this position-which commands ABRI's political policies-reflected the rise in fortunes of Muslim officers typified by the promotion of Gen. Feisal Tanjung who had replaced Try Sutrisno as ABRI Commander in March 1993.

38 Ibid., pp. 43-45.
} 
Hartono's assessments were not unique and were widely shared by the state administrators. However, as seen in the Lemhannas document on national vigilance, this shared perception effectively opened discursive space for ABRI to assert the need for strengthening ideological-political control under the flag of "latent danger." Hartono's promotion to the position of Army Chief of Staff in February 1995 strengthened ABRI's inclination to adopt this approach in political practice. The starting point for this development should be sought in the context of the changing Suharto-ABRI relations since the 1988 MPR session which was, as discussed earlier, colored by ABRI's overt frustration with Suharto's choice of Sudharmono as vice president.

\section{Transformation of Suharto-ABRI Relations}

The lingering antagonism between Suharto and the ABRI leadership had been reflected in events such as the dissolution of Kopkamtib and the creation of ICMI. For Suharto, both these moves worked to undermine the influence of Murdani-linked officers and insure that ABRI was fully under his control. These attempts were accompanied by his move to limit the freedom of the current ABRI leaders to conduct their dwifungsi mission in politics. This attitude was apparent in a statement made by Suharto in November 1990. As he was receiving the visit of high-ranking officers following the ABRI Leadership Meeting (Rapim ABRI 1990), he emphasized that ABRI's role in society should be tut wuri handayani. ${ }^{39}$ Since it was Suharto, as President and Supreme Commander of Armed Forces, who implied a need to shift ABRI's posture, this inevitably gave democratic advocates some ammunition to question ABRI's dwifungsi. Though ABRI denied that the president had any such plans, critics kept asking about Suharto's apparent intention to weaken ABRI's political role and questioning to what extent ABRI would actually change its current posture in line with the Presidential request. Suharto's statement thus resulted in the escalation of critical debate on ABRI's role in politics. ${ }^{40}$

Suharto's attempt to undermine the military influence under the Murdani-Sutrisno leadership was also apparent in the handling of the so-called Dili incident in which ABRI troops fired on thousands of demonstrators in Dili, East Timor, on November 12,

\footnotetext{
39 A Javanese expression to describe how a father supports his young children from behind as they learn to walk. This is one of three educational principles introduced by Ki Hadjar Dewantara who was a founder of Taman Siswa, an educational institution established in 1924. Together with tut wuri handayani, there are: ing madya mangun karsa which respectively means "to be a driving force of children when in their midst" and ing ngarsa sung tuladha which means "to lead from the front." These were adopted as the three leadership principles of ABRI. See Suharto's autobiography, Suharto: Pikiran, Ucapan, dan Tindakan Saya (Jakarta: PT Citra Lamtro Gung Persada, 1989), p. 426, about these concepts. For Suharto's political use of these concepts, see Saya S. Shiraishi, Young Heroes: The Indonesian Family in Politics (Ithaca: Cornell Southeast Asia Program, 1997), pp. 9-13.

40 Among the Murdani circle, such a development was viewed with the suspicion that Suharto was unwilling to protect ABRI's corporate interest embodied in the dwifungsi doctrine. This perception was reflected in a statement in 1994 by Gen. Edi Sudradjat-who replaced Murdani as Defense Minister in 1993-which insisted that the concept of tut wuri handayani had been manipulated for a certain political interest. See "Manipulasi 'Back to Basic' and 'Tut Wuri Handayani' Menyesatkan," Kompas, February 22, 1994.
} 
1991.41 On the day after the incident, the ABRI Commander (Pangab), Gen. Try Sutrisno, condemned the demonstrators for causing chaos and claimed that the troops were forced to shoot when the mob attacked soldiers brutally. However, Suharto-as ABRI's Supreme Commander-quickly decided to dismiss two officers, Brig. Gen. Warouw and Maj. Gen. Sintong Panjaitan, who, although not directly involved in the shooting, were considered formally responsible for violations taking place within their areas of command.42 It was the first time in the New Order period that general-ranking officers were held responsible for the shooting of civilians by their troops. In addition, 19 soldiers directly involved in the shooting were court-martialed. Suharto's measures were resented by many officers who believed that the shooting was proper. As a result, officers began to feel that Suharto was not willing to protect ABRI's institutional interests. ${ }^{43}$ The vast international pressure brought to bear on Indonesia after the Dili killing was the primary factor that pushed Suharto to set up the National Commission for Human Rights (Komnas HAM) in December 1993. From the perspective of ABRI, now increasingly disenchanted with the president, this "government" body to check ABRI's human rights abuses was seen as another attempt by Suharto to create a tool to help him publicize military problems that would be used to his political benefit. ${ }^{44}$

The military leadership under Murdani and Try Sutrisno was not silent. In the June 1992 general election, ABRI adopted a "neutral" attitude toward Golkar and also

41 The Indonesian official account for the death toll was nearly 50 . But foreign human-rights organizations assessed it as around one hundred to three hundred.

42 Warouw was the Commander of East Timor Operations (Pangkolakops), and Panjaitan was Commander of the Nusatenggara region which covered East Timor. These two generals were thought to be Murdani's men. Warouw - a Menadonese Protestant-was said to have conducted a discipline campaign, including the charging of over three hundred ABRI personnel since he took office in December 1989. This "clean up" campaign was said to be opposed by local gangs with military links (called ninja), and by Lt. Col. Prabowo-Suharto's son-in-law-who had served for some time in East Timor. See The Editors, "Current Data on the Indonesian Military Elite," Indonesia 53 (April 1992): 98-99. Many believed that Prabowo had established a strong tie with ninja especially after he was rescued by a gang led by a man called Hercules when kidnapped by pro-independent guerrillas (Fretilin) in the mountains. For the conflict between the Murdani and Prabowo groups in the Dili incident, see, for example, Herb Feith, "East Timor: The Opening up, the Crackdown and the Possibility of a Durable Settlement," in Indonesia Assessment 1992: Political Perspectives on the 1990s, ed. Harold Crouch and Hal Hill (Canberra: Department of Political and Social Change, Research School of Pacific and Asian Studies, Australian National University, 1992), p. 70. It is also suggested that the order to shoot demonstrators certainly did not come from the two sacked generals in East Timor, but possibly from an officer with the rank of lieutenant colonel in Jakarta. For this account, see Takashi Shiraishi, "Kokugun: Sonosedaikoutai to henbou," [Indonesian Military Elite: Generation Change and Its Implications]," in Gendai Indonesia no Seiji to Keizai: Suharto Seiken no 30 nen [30 Years of Suharto Government: Its Political and Economic Performance], ed. Akio Yasunaka and Norio Mihira (Tokyo: the Institute of Developing Economics, 1995), p. 119. It has, therefore, been suspected that Lt. Col. Prabowo-who had special access to the President and was helping the purge of Murdani-linked officers-engineered the incident in Dili to further the purge.

43 Such an assessment was frequently expressed by the intellectual officers at the Army Staff and Command College (Seskoad) during 1992-1997. They supported Sutrisno's statement above and criticized the attitude of the "government" which bent the "national interest" in facing the international pressure. The details are discussed in my The Military and Democratization in Indonesia: The Developing Civil-Military Discourse during the Late Soeharto Era, 1988-1998 (Ph.D. diss., The Australian National University, 1999 [forthcoming]), Chapter 3.

44 For this account, see Human Rights Watch/Asia, The Limits of Openness (New York: Human Rights Watch, 1994), p. 126. 
"tolerated" retired officers who supported the Indonesian Democratic Party (PDI). 45 The implication was clear. It was ABRI's reminder to Suharto that the established New Order political system could not be maintained without ABRI's active support. ABRI's response was highlighted in the vice-presidential election at the MPR session in March 1993. In February, Murdani's aide, Lt. Gen. Harsudiono Hartas (Kassospol), announced ABRI's nomination of the Pangab, Try Sutrisno, as the next vice president. In facing such a high-profile challenge, Suharto-who is said to have favored Habibie-finally accepted the fait accompli, choosing Sutrisno as his running mate for the Sixth Development Cabinet (1993-1998). ABRI's challenge to Suharto was seen as the breaking of a taboo, as it had been a New Order practice for ABRI to wait for Suharto to nominate his own vice-presidential candidate before announcing its own preference. As the finale of this Suharto-ABRI conflict, officers such as Murdani, Sutrisno, and Hartas were all removed from the military structure. ${ }^{46}$

This 1993 event was a turning point in Suharto-ABRI relations. From Suharto's perspective, it was urgent to reconstruct the military so that it would be amenable to him. Dismantling the legacy of Murdani's ABRI and recruiting loyalist officers were the two major goals. Suharto's political survival rested largely on how he could transform ABRI within the next five years before the 1998 presidential election. Regardless of whether or not he himself would choose to stay in office, establishing an amenable military was necessary for his management of succession. A structural impediment encountered by Suharto in this effort was the generation gap. As a remnant of the revolutionary generation, Suharto seemed to have been less capable of judging loyalist officers of the new generation-except for his military aides. Inevitably, Suharto started to accept the advice of trusted cronies in selecting officers who would occupy strategic positions. The role of his family, including Habibie, whom Suharto had known since Habibie was a child, became increasingly apparent in military promotion practices. ${ }^{47}$ It was against this background that Prabowo's rise toward the top military position at the time of the 1998 MPR was widely perceived as inevitable, although it deviated from the standard promotion procedures. ${ }^{48}$

\footnotetext{
45 Interview with Lt. Gen. (ret) Hasnan Habib, former Chief of Staff of Defense Ministry (1973-75) and Ambassador to the United States, August 9, 1996. Although Golkar obtained the majority of votes in the 1992 election, it lost vote from 73 percent in 1987 to 68 percent.

${ }^{46}$ Murdani was replaced by Army Chief Gen. Edi Sudradjat. Edi-a secular-nationalist officer-enjoyed a range of support within the military but the position of Defense Minister was less influential as a place from which to consolidate an independent power base. However, he was a close associate of Murdani and frequently made statements critical of the government and the new ABRI leadership led by Gen. Feisal Tanjung, a devout Muslim and long-time friend of Habibie. Gen. Feisal became ABRI Commander in May 1993 with the strong recommendation by Habibie to Suharto. Feisal's Islamic orientation also synchronized with Habibie's desire to cultivate military support for his ICMI.

47 Apart from Feisal Tanjung, Wismoyo Arismunandar who replaced Edi Sudradjat as Army Chief in May 1993 was a brother-in-law of Suharto's wife. In February 1995, Wismoyo was replaced by Hartono who had been close to Prabowo and Siti Hardijanti Rukmanan, or Mbak Tutut, Suharto's eldest daughter.

48 Such a trend was already apparent in December 1995 when Prabowo was promoted to the Commander of Special Forces (Kopassus) and became a brigadier general. According to the codified promotion standard, it normally takes twenty to twenty-five years after graduation from the military academy to reach the rank of colonel and a minimum of twenty-three years to become a one-star general. Buku Petunjuk Dasar Tentang Pembinnan Prajurit ABRI [Kep/06/X/1991] (Mabes ABRI, 1991), pp. 81, 96. Prabowo, who was a graduate of the military academy (Akabri) in 1974 was clearly deviating from the
} 
The ABRI leadership under Feisal Tanjung, who replaced Edi Sudradjat in May 1993, further adapted itself to the direction of Suharto's shifting political preferences, as indicated by two events. First, in the Golkar Congress in October 1993, Feisal announced that ABRI would not nominate a candidate for Golkar Chairman, a decision that expedited an effort by the Suharto-Habibie group to promote the "civilianization" and ICMI-zation of Golkar by installing Harmoko (Information Minister and a member of ICMI's Advisory Board) into the position. Feisal's remarks indicated that $A B R I$ would not take a stand for or against the first civilian chairman of Golkar and reversed Defense Minister Edi Sudradjat's previous statement that ABRI was ready to provide ten to twelve candidates for the race for the Golkar leadership. ${ }^{49}$ Harmoko was finally selected but ABRI was not united on this matter, as indicated by the Deputy Head of F-ABRI, Maj. Gen. Sembiring Meliala, who revealed his displeasure by saying that Harmoko and Habibie were nothing without the president and when the president was no longer in power, they would vanish. ${ }^{50}$ The Feisal circle quickly responded, as Brig. Gen. Syarwan Hamid (Head of ABRI's Information Center-Kapuspen) criticized Sembiring's assessment as wrong and said that it exceeded the limits of the individual's right to free speech. ${ }^{51}$ But even he, while countering Feisal's critics, could not deny growing concern within the military about Feisal's leadership and about ABRI's subordination to Suharto-Habibie who seemed to undermine the established role of the military in politics.

Second, in January 1994, ABRI's central intelligence agency, BAIS (Armed Forces' Strategic Intelligence Body), which had been developed by Murdani, was liquidated and replaced with the less powerful BIA (ABRI Intelligence Body). The end of BAIS further encouraged the dismantling of the personal network of Murdani (dubbed as de-Murdani-zation), while at the same time it diminished the organizational basis of autonomous military power that could evolve beyond Suharto's control. 52

norm. One retired officer put it as follows. "Prabowo has a toll-road ticket-meaning he can bypass the jam of waiting officers. We are concerned about the impact of his case on lower-ranking soldiers. . . I am not surprised if young soldiers dream of Prabowo and gradually disregard the moral disciplines they have believed until today." Confidential interview, August 1996. Such concerns are reflected in the comment by a serving two-star general who insisted that ". . today's ABRI faces declining independence from the President, and ABRI can never be professional under the current situation." Interview, September 1996.

49 "Mencari Ketua, Menyiapkan Suksesi," Tempo, May 8, 1993.

50 For Sembiring's comment, see "Mayjen TNI RK Sembiring Meliala: 1000 Orang DPR/MPR Jangan Dianggap Togog," DeTik, October 27 - November 2, 1993. Gen. (ret) Rudini-former Army Chief (1983-86) and Interior Minister (1988-93) - also claimed that the procedures of the Congress led by Habibie were not transparent and democratic. Professor Juwono Sudarsono at University of Indonesia, a civilian academic who was popular among intellectual officers, saw Sembiring's comment as representing ABRI's mainstream view. See "Army General's Comment Whips Up Indonesian Storm," Reuters, November 1, 1993. Sudarsono later became vice-governor of Lemhannas.

51 "Pernyataan RK Sembiring Dinilai Keliru," Kompas, October 31, 1993. Together with Feisal, Syarwan Hamid had a strong Muslim background.

52 Admiral (ret) Sudomo, who was Murdani's old ally and was still in Suharto's inner circle, explained the scrapping of BAIS as a necessary step because it had deviated from its original task as seen in its manipulation of sociopolitical organizations. See "Bais ABRI Perlu Restrukturisasi," Kompas, January 18, 1994. Perhaps, the "deviation" here only meant activities which were perceived as not reflecting Suharto's vision. In this light, the PDI Congress which elected Megawati Sukarnoputri, a daughter of Sukarno, as the new chairperson in December 1993, was interesting. Murdani's trusted man in BAIS, Brig. Gen. Agum 
94 Jun Honna

The transformation of ABRI's high command in the post-Murdani period was managed through such processes. Suharto's efforts to reconstruct presidential-ABRI relations on a new basis, and his search for loyalist officers to this end, were increasingly mediated by Habibie and Feisal and also by Prabowo. When Hartono was promoted to Army Chief of Staff in February 1995, his elevation was interpreted as the result of an initiative by Prabowo. ${ }^{53}$ The renewed ABRI leadership led by Feisal and Hartono was pro-ICMI and amenable to the First Family. It was this military leadership that Suharto relied on to prepare for the smooth handling of both the 1997 general election-which was expected to face a serious opposition movement centered on Megawati-and the 1998 presidential election, which must not be marred by disturbances of the sort that had been happened in recent memory, i.e. Ibrahim Saleh's interruption in the MPR and Harsudiono Hartas' early nomination of the vice president.

Against this political background, the new ABRI leadership was inclined to seek a rationale to legitimize political repression against the widening popular criticism of the Suharto regime and the growing societal demands for democratic keterbukaan. Here, the decision to rely on the routinized kewaspadaan approach which had been institutionalized by the previous ABRI leadership was understandable, as it had been regarded as a legitimate practice within the military. Perhaps it was perceived as a painful task, since these actions were certain to decrease the people's trust in ABRI. But the new military leaders found a hope; their kewaspadaan approach might appeal to Muslims if it used the Islamic cause as a rallying point-as Suharto did in the mid1960 s when the army mobilized Muslim masses to eliminate PKI supporters under the flag of jihad. ${ }^{54}$

\section{Kewaspadaan Political Programs during the Final Years}

The Feisal-Hartono leadership therefore adapted the established kewaspadaan doctrine. As discussed earlier, the identification of pembangunan as potentially fertile

Gumelar (Director of the Internal Affairs Section in BAIS and later Kopassus Commander) was one of the army officers handling the case. ABRI issued permission to the PDI to hold the Congress in Jakarta which was almost certain to elect Megawati-a popular opposition figure-as the chairperson. The liquidation of BAIS took place just after this event, and Gumelar (Kopassus Commander) was also sidelined to the post of Chief of Staff of the North Sumatra Division in September 1994. This was commonly seen as reflecting Suharto's unhappiness with Gumelar's role in the PDI issue. However, according to an officer who has known Gumelar well, Gumelar told him: "how was it possible for me to act without Suharto's order?" Suharto, at that time, told Gumelar to settle the PDI's leadership problem, so he interpreted Megawati's elevation as acceptable. It was then Prabowo who informed the President that the operation was unsuccessful, after which Suharto decided to sideline Gumelar (personal communication, 1998). Agum's successor as Kopassus Commander was Brig. Gen. Soebagyo Hari Siswoyo, whose promotion was also said to have been recommended by Col. Prabowo (Deputy Commander of Kopassus at that time). This promotion was seen as a part of Prabowo's factional consolidation within ABRI.

53 Both Hartono and Prabowo established a political think-tank, Center for Policy and Development Studies (CPDS) in 1995, which had a strong Muslim and anti-Murdani orientation. As mentioned earlier, Hartono also cultivated a very close relationship with Tutut.

54 See, for example, Geoffrey Robinson, "The Post-Coup Massacre in Bali," in Making Indonesia: Essays on Modern Indonesia in Honor of George McT. Kahin, ed. Daniel S. Lev and Ruth McVey (Ithaca: Cornell Southeast Asia Program, 1996), pp. 127, 140. 
ground for subversives was already a part of the standard interpretation of Balatkom. Under the new military leadership, the details of this doctrine were frequently adjusted to cultivate Islamic sympathy. Discussion of the problem of the widening social-economic gap, which was also cited by democratic advocates critiquing New Order developmentalism, came to be focused on Chinese-Indonesians. Reference to the gap was often a code for appealing to Islamic sentiments against rich Chinese. Although publicizing the simple dichotomy between the rich-Christian-minorityChinese and the poor-Muslim-majority-Indonesian threatened to stir up ethnic disharmony, the political usefulness of this approach was still considerable. If this approach was coupled with hardline thinking on globalization, as officially formulated by Lemhannas under Hartono, the missing link between the Islamic cause and support for the regime could be found by the promoters of ABRI's doctrine. Gen. Hartono's close associate, Brig. Gen. Farid Zainuddin, for example, wrote in a Lemhannas journal as follows:

The West is always antagonistic to Islam. This is not unrelated to the recent international campaign for political liberalization [by the West] . . which has also been promoted in Indonesia as the revival of Islam becomes apparent. . . . It is globalization that facilitates this [campaign]. It [globalization] also strengthens the international network of non-pribumi business which has dominated the Indonesian economy since the beginning [of the New Order]..$^{55}$

This proposal that the West be perceived as a force threatening Islam evokes the concept of globalization to emphasize the "Chinese problem" in economic life. This interpretation of a new Western threat is expected to promote Islamic "nationalism" and demonstrate ABRI's sympathy to it. Then, it provides an opportunity to argue that the democratic movement-which is allegedly manipulated by Western antiIslamism-should be treated with suspicion by Muslims.

The military leadership also strove to invent a new logic to identify evolving democratic pressure from society as reason for the need to sustain the Balatkom campaign. The opportunity arrived in July 1995, when Suharto decided to release some G30S-related political prisoners, including Soebandrio, Omar Dhani, and Soetarto. ${ }^{56}$ The release of former political prisoners had been strongly demanded by the Komnas HAM from a human rights perspective. When Minister of Justice, Oetojo Oesman, announced Suharto's plan to grant amnesty to these figures, ABRI Commander Feisal Tanjung-who had claimed before that there were still more than three hundred PKI supporters in society-responded with discontent and insisted that this issue had to be handled carefully and would take time. ${ }^{57}$ At the same time, the military leadership reintroduced the latent danger theory to combat the opinion in society that ABRI's

55 Brig. Gen. Farid Zainuddin, “Reaktualisasi Peran Sospol ABRI Dalam Rangka Memantapkan Kemandirian Bangsa," Majalah Ketahanan Nasional 63 (1995): 109. Non-pribumi refers to ethnic Chinese Indonesians. Zainuddin was Hartono's assistant for political-security affairs and then promoted as the Head of BIA in August 1997.

56 Soebandrio was the former deputy prime minister and Omar Dhani was the former Navy Commander, while Soetarto was a police intelligence officer during the Sukamo era. None of the three was a PKI member.

57 "Silang Pandangan Mengampuni PKI," Gatra, July 22, 1995. However, there was no explanation of how three hundred people could threaten national stability. 
vigilance was no longer relevant in the current stable situation. Maj. Gen. Syarwan Hamid-who had been promoted to Assistant of Sociopolitical Affairs to Kassospol (Assospol Kassospol) in March-stated that:

... communism has in fact become bankrupt, but its "teaching" is still alive today. For example, when we listen to the music, ABRI does not see the singer but listens to the song, and tries to recognize whether or not the melody comes from the old song even though the musical instrument is different from the past. $^{58}$

Having insisted that the communist song could be played on new instruments, Syarwan asserted that current political issues such as keterbukaan and human rights provided excellent opportunities for singing the song.

As seen above, the detachment of the subversive "method" from the "ideology" of communism seemed to have become an established piece of Balatkom, and the concept of globalization had greatly helped ABRI in developing, and then manipulating, this interpretation of what it meant to be "subversive" or potentially "communist:" ABRI's effort to link the foreign threat to domestic political instability was nothing new, as it had been repeated since the beginning of the New Order. ${ }^{59}$ What could be seen in mid1995, however, was the renewal of its method and redefinition of its target. Now, in the age of the post-Soviet world order, the alleged "outside threat" shifted from the communist doctrines to communist-type activities fomented by the penetration of universal values, not communist values. The target of repression was no longer limited to communist supporters, but was expanded to include the popular movements conducting anti-regime activities; this was accomplished by identifying them as similar to the communist ones.

It soon became apparent that this technique was politically operative. In late 1995, political society was occupied with the issue of "formless [communist] organization" (Organisasi Tanpa Bentuk, or OTB), raised by ABRI's Chief of General Staff (Kasum), Lt. Gen. Soeyono, who identified fifteen government critics as OTB figures. He publicly explained that there were two groups of communists-one consisted of former PKI supporters and the other consisted of those who had been influenced by the first group and now tried to discredit the government by using the issues of human rights, democratization, and environmental protection. ${ }^{60}$ Furthermore, Soeyono insisted that

58 See Syarwan's interview in "Dengar Lagu, Bukan Orangnya," Gatra, July 22, 1995. Emphasis added.

59 For example, soon after the launching of the New Order, BAKIN's house magazine, Chas, conducted a campaign to link the Wall Street Journal - which had published a series of articles on miliary corruptionand the Soviet KGB as both part of the "outside threat" to Indonesia's domestic stability. Here the remnants of the PKI were identified as the hypothetical domestic agents of the threat. I am indebted to Professor Ben Anderson in making this point.

60 See "ABRI Names Faces Behind Incidents," Jakarta Post, October 17, 1995 and "Letjen TNI Soeyono: Cara-Cara PKI Sudah Dilakukan Terang-Terangan," Forum Keadilan, October 23, 1995. Soeyono was a former Presidential adjutant. The group of fifteen alleged critics consisted of: five academics, including George Adicondro, Arief Budiman, Kuwat Triyanto, Harsono, Lie Sing Tew-all had links with the Christian University of Satya Wacana; a labor activist, Mochtar Pakpahan; an anti-regime novelist, Pramoedya Ananta Toer, who received the Roman Magsaysay Award in 1995; a vocal Muslim parliamentarian, Sri Bintang Pamungkas, who was kicked out of parliament; human-right lawyers Mulyana Kusumah and H. J. C. Princen; a former Minister during the Sukarno period and long-time political prisoner, Oei Tjoe Tat; a Chinese student living in Canada and active on the Internet, Paul Salim; 
the PKI had used "agitation and propaganda" (agitprop) in the past, the same methods which were now being used by these figures to criticize the government, and therefore they were identified as OTB. In our analysis of the developing kewaspadaan-Balatkom discourse, Soeyono's interpretation seems to be the ultimate model which made it possible for ABRI to claim that virtually any demonstration against government policy used communist methods. Linking the OTB issue and the alleged impact of globalization, his theory attacked both the Internet and NGOs, asserting that current indications of communist emergence were almost the same as in 1965, except that the method of the contemporary subversives was different, as they could infiltrate the nation via the Internet. ${ }^{61}$ Regarding the NGOs, which had already become important political actors through their efforts to expose ABRI's frequent human rights abuses, he warned that "we now know their color and will scrutinize them to reveal many of their grey activities," insisting on the possible link between the transnational human rights movement and the latent danger of communist infiltration. ${ }^{62}$

The OTB concept was carried further by other officers who followed the SoeyonoSyarwan approach. Maj. Gen. Yusuf Kartanegara, the Commander of the Central Java Kodam (Military Area Command), announced that five ex-PKI figures in Purwokerto had attempted to gather forces to plot the establishment of the negara Islam (Islamic state), while Colonel Mat Ishak, Korem Commander in Padang, Central Sumatra, asserted that a recent riot in Jambi had been didalangi (manipulated) by former PKI members, and Maj. Gen. Imam Utomo, East Java Kodam Commander, rode on the wave by stating that a recent riot in his command area, which targeted the house of a local parliamentarian, was possibly led by OTB members. He also claimed that East Java was a "storehouse" (gudang) of OTB. Similarly in the West Java Kodam, its

a hugely popular public speaker and supporter of Megawati, Permadi; a retired general purged after 1965 for his links with Moscow and his leftist past, Soehario Padmodiwirio; and an undergraduate student, Petrus Hariyanto. Many of them were prominent democratic-reform advocates, and those who had conducted popular political activities outside the regime were now easily labelled as potential threats to the regime stability by utilizing the OTB concept.

61 Ibid. ABRI's concern about the Internet-which was beyond the state's control of information-led to the establishment of a special Internet unit in ABRI headquarters. This was announced a few days after Soeyono's OTB statement on 16 October. See "Perangi Info Sampah ABRI Masuk Internet," Republika, October 20, 1995. On the political impact of the Internet "revolution," see David T. Hill and Krishna Sen, "Wiring the Warung to Global Gateways: The Internet in Indonesia," Indonesia 64 (October 1997): 67-89. It was thought that the main objective of this unit was the collection of information about anti-government activities and-as described by an officer involved in this project- "counter-information" on the Internet (interview, October 1996).

62 Quotations are from Soeyono's interview cited above, published in Forum Keadilan, October 23, 1995. This view was supported by Syarwan Hamid who insisted that Liem Soei Liong, an activist of Amnesty International in London and general secretary of Tapol magazine, was an OTB figure who had tremendous influence on all NGOs in Indonesia. According to Syarwan, ABRI had already identified thirteen NGOs which exploited the issues of human rights and democratization. See his interview in "Assospol ABRI Syarwan Hamid: PKI Kini Sedang Bermetamorfosa," Forum Keadilan, November 6, 1995. The prominence of NGOs in the late New Order politics was paralleled by the growing wave of labor strikes that started about 1990. These strikes had been supported and encouraged by many human rights NGOs. Details are analyzed, for example, in Vedi R. Hadiz, "Workers and Working Class Politics in the 1990s," in Indonesia Assessment 1993: Labour-Sharing in the Benefits of Growth?, ed. Chris Manning and Joan Hardjono (Canberra: Department of Political and Social Change, Research School of Pacific and Asian Studies, Australian National University, 1993), pp. 186-200. ABRI's hostility to these NGOs might be intensified by the fact that military personnel were often hired by enterprises as their security guards, i.e. strikebreakers. 
Commander, Maj. Gen. Tayo Tarmadi, warned that OTB figures had benefited from the current economic gap in society and penetrated into religious organizations to conduct dangerous activities. ${ }^{63}$ None of the three Kodam Commanders in Java provided any explanation about the dubious link between Marxist atheism and religious fanaticism. But they publicly adopted this new version of old regime language, which now exploited the globalization concept to strengthen military pressure on democratic advocates. In effect, many of the major issues of the civilsociety movement-such as human rights, democracy, NGOs, labor-land rights, and economic injustice-were incorporated in the scope of kewaspadaan-Balatkom discourse under the Feisal-Hartono ABRI leadership.

Several critics responded to ABRI's ghost-hunt by arguing that this was all merely a repetition of old rhetoric meant to promote $A B R I$ 's political bargaining power vis-àvis the emerging democratic forces. ${ }^{64}$ It was interesting to note that the former vice president Sudharmono, who had earlier been the target of rumors branding him as communist, responded negatively to the OTB campaign, by warning against "instantly labeling certain people as OTB or having an 'unclean [family] environment' (tidak bersih lingkungan)." The Minister of the Environment, Sarwono Kusumatmadja, a reformist Minister, also expressed his disapproval by saying that the campaign was reminiscent of the 1970s.65 The father of the Tarpadnas project, Lt. Gen. (ret) Soebiyakto, also asserted in 1997 that: "today's ABRI insists on the latent danger of PKI, or formless [communist] organizations (OTB), and always claims that there is a PKI-ghost behind democratic movements. But they are nonsense, there is no threat from the PKI any more."66 As widely believed, the campaign might have been motivated by practical political calculations relating to the upcoming general election in 1997. On the other hand, considering ABRI's institutional routine of kewaspadaan maintenance, the OTB campaign in 1995 seems to have been the final step to "free" the doctrinal utility of Balatkom from the bounds of history.

63 All comments are from "Mewaspadai Lawan Baru: Tanpa Bentuk," Forum Keadilan, November 6, 1995.

64 Many critics also saw that the campaign had political goals. A human rights activist, H. J. C. Princen argued that the campaign was ABRI's effort to emasculate government critics before the 1997 general elections, while Paul Salim, an Internet commentator, argued that the government-which had been relying on repressive measures-needed the campaign to legitimize its theory that stability was endangered. Both Princen and Salim were included in Soeyono's list of fifteen OTB members, cited above. For their responses to the campaign, see "Curiga Lima Belas Dalam OTB," Forum Keadilan, November 6, 1995. In January 1996, as if to sustain the campaign, the ICMI-sponsored newspaper, Republika, published an article (January 5,1996 ) which indicated that many children of ex-PKI figures had a tendency to vote for the PDI in elections. This was obviously aimed to discredit the PDI-particularly Megawati. The growing pressure on the grass-roots movement was soon resisted by a group of 16 NGOs which published "A Joint Statement on the New Order Culture of Violent Approach Toward Indonesian Citizens," (English) in May 1996. The statement strongly condemned Soeyono and Syarwan Hamid for their OTB labeling of NGOs, and insisted that NGOs' activities were based on the constitution.

65 The comments of Sudharmono and Sarwono are from "Mewaspadai Lawan Baru: Tanpa Bentuk," Forum Keadilan, November 6, 1995. Komnas HAM-a "government" body to monitor human rights abuses-also complained at a meeting with the Coordinating Minister of Political and Security Affairs (Menko Polkam) Soesilo Sudarman and Lt. Gen. Soeyono, and warned against the baseless arguments being developed in the OTB polemic. "Komnas HAM Minta Klarifikasi Soal OTB Pada Menko Polkam," Kompas, October 26, 1995.

66 Interview, January 8, 1997. Soebiyakto's rejection of OTB seemed to be derived largely from his antipathy - strongly shared by former Murdani allies-to Suharto and the new ABRI leadership. 
In facing these criticisms, the military leadership responded in two ways. First, it reiterated the established interpretation of Balatkom. Lt. Gen. Moetojib, who had replaced Hartono as Lemhannas Governor, wrote in his house journal that the current issues of democratization, human rights, and keterbukaan had all been strongly influenced from abroad, and that discussion of these issues encouraged the formation of critical public opinion-including criticism of ABRI's political role-which in effect threatened national stability. ${ }^{67}$ Here, without referring to Balatkom, civil-society concepts were all automatically identified as threats to stability and the object of kewaspadaan. The consolidation of ABRI's interpretation of Balatkom was more evident in reports from the territorial staff section in ABRI headquarters. In its regular report internally circulated in early 1996, the OTB issue attracted special attention. ${ }^{68}$ After describing the chronological events leading to the emergence of public debate over the OTB in the previous year, the report claimed that OTB members believed in the communist technique as their most effective tool. The alleged technique relied on the "theory of contradiction" [sic] to encourage conflict between groups, for instance between the rich and the poor, between religious groups, between ABRI and laborers, and between old and young people. By using this method, the report continued, these OTB elements created antagonistic conditions and conflicts of interests in society, which would lead to rioting and political instability. ${ }^{69}$

Coupled with these attempts by ABRI to standardize its new interpretation of Balatkom embodied in the OTB theory, the military's second response to criticism was a search for evidence-or the construction of the reality of Balatkom in the current situation. First, academics became the target. In October 1995, Brig. Gen. Djoko Subroto, Chief of Staff of the Central Java Kodam, announced that the Kodam's investigation found proof that three academics in the Christian University of Satya Wacana had been involved in communist activities in the distant past. Asked about possible action to be taken against these three, Djoko suggested that the University Rector had the power to act, thus placing the case beyond ABRI's direct responsibility. ${ }^{70}$ The pressure on campus politics continued as Lt. Gen. Soeyono in November warned that he could bring a military tank to any university if necessary, even if there had been no formal request for tanks. ${ }^{71}$ His threat was a response to the growing number of student demonstrations in recent years. This high-profile warning to students was followed in December by the arrest of Petrus Hariyanto, a prominent

${ }^{67}$ Moetojib (Letjen TNI), “Stabilitas Nasional Sebagai Landasan Kokoh Bagi Pembangunan Politik dan Ekonomi," Telstra 38 (January-February 1996): 10. Since March 1996, Moetojib served as the head of BAKIN until replaced by Lt. Gen. (ret) Zein A. Maulani in September 1998.

${ }^{68}$ Staf Teritorial ABRI, Tinjauan Teritorial (Jakarta: Mabes ABRI, No. Triwulan I 1996/1997). Tinjauan Teritorial is the quarterly report of ABRI Headquarters' Territorial Section (Ster ABRI).

${ }^{69}$ Above references are from ibid., p. 3. The "theory of contradictions" is Mao's contribution to modern political language.

70 See "Kodam IV Teliti Dugaan Tiga Dosen UKSW Sebagai Eks PKI," Suara Merdeka, October 26, 1995. The three faculty members were Kuwat Triyanto, Harsono, and Lie Sing Tew. They faced this accusation in October 1994 when the faculty conducted a "democratic" strike against the dismissal of Dr. Arief Budiman-a sociologist and long-term New Order critic-who had protested against the improper procedures used in the selection of the University's new rector. The allegations against the three reemerged in the military's attempt to seek evidence for Soeyono's OTB approach.

71 "Saya Bisa Bawa Tank ke Kampus," Kompas, November 28, 1995. 
student activist and Secretary General of SMID (Students in Solidarity for Democracy in Indonesia) who was included in Soeyono's list of fifteen OTB figures and was suspected of leading a recent petition movement to the Dutch Embassy.

Together with academics, NGO activists were also targeted in ABRI's effort to prove Balatkom was a reality. In May 1996, a book published in December the previous year was banned by a Supreme Court decision. The title of the book was Bayang-Bayang PKI, or Shadows of the PKI, which was edited by some prominent political activists. The banning was recommended at first by the Publications Investigation Team of Bakorstanas (the Coordinating Agency for the Maintenance of National Stability) which concluded in March 1996 that, despite the stated purpose of the book as a general reference for young people studying G30S/PKI, the content was marred by historical distortions, notably distortions meant to discredit ABRI and the national leadership. ${ }^{72}$ In the report's conclusion, ABRI labeled this book as extremely dangerous to young readers who had never experienced the G30S/PKI incident. After this, ABRI's surveillance of NGOs via the territorial apparatus from Kodam to Koramil (Military Subdistrict Command) was tightened. It was in the midst of such tension between NGOs and ABRI that Megawati's PDI was toppled and a physical clash between the two sides triggered a large riot on July 27 in 1996, followed by ABRI's purge of NGO activists that especially targeted the People's Democratic Party (PRD)a student NGO which had recently declared itself to be a political party. Let us examine this development.

The ABRI Headquarters received an order from Suharto to intervene and overthrow the PDI chairman, Soerjadi, at the party congress at Medan in July 1993. Three years later, the ABRI Commander, Feisal Tanjung, claimed that the PDI leadership conflict was still unsolved and, acting again under instructions from Suharto, he called for another PDI congress in June 1996 at Medan. This time the goal was to topple Megawati-the only politician with a chance to threaten Suharto's stranglehold on Indonesian politics-and reinstate Soerjadi. The rebel congress elected Soerjadi to replace Megawati and soon received government endorsement. Megawati then filed legal suits against senior government and military officials, including Feisal,

\footnotetext{
72 Bakorstanas was established to replace Kopkamtib in 1988. The assessment by Bakorstanas is in Staf Teritorial ABRI, Tinjauan Teritorial, pp. 5-12, with the title, "Hasil Penelitian Tim Karya Tulis Bakorstanas Terhadap Buku 'Bayang-Bayang PKI."' The report demanded that the Supreme Court immediately ban the book and also asked ABRI's territorial apparatus to watch out (mewaspadai) for the circulation of this book in society. In denouncing the book as a "historical distortion," Bakorstanas cited some remarks in interviews with old political figures conducted by the book's project team. For example, Manai Sophiaan, former Secretary General of the pro-Sukarno Indonesian Nationalist Party (PNI), was quoted describing his recollection of the situation in 1965; he insisted that Suharto surely knew about the coup attempt because one of the plotters, Colonel Latief, was an old friend of Suharto and would have let him know the plan a day before it happened. See Stanly, ed., Bayang-Bayang PKI (Jakarta: Institut Studi Arus Informasi, 1995), p. 90. In his autobiography, Suharto himself admits that Latief came to see him, but there is no description about the talk between the two. Suharto, Soeharto: Pikiran, Ucapan, dan Tindakan Saya, p. 118. This work also discussed a survey conducted by the team of Institut Studi Arus Informasi (the Institute for the Studies on Free Flow of Information)-a research and publishing house established by Goenawan Mohamad, editor of Tempo which was banned by the government in 1994-in Jakarta. Among one hundred respondents (not randomly selected as many of them were students), more than 70 percent disagreed with the government policy of broadcasting its semi-official G30S/PKI film every year, showing that the Balatkom interpretation of history was rejected by those who were born in 1970s. See Stanly, ed., Bayang-Bayang PKI, pp.157-159. These points help explain why Bakorstanas decided to ban the book.
} 
alleging that they manipulated the congress in order to divide the party. She also launched a daily "free speech forum" (mimbar bebas) at the party headquarters in central Jakarta. The forum was joined not only by Megawati's PDI supporters, but also by student groups and NGOs which demanded democratization. Bambang Widjojanto of the Indonesian Legal Aid Institute (YLBHI) defined the movement as "people's power," suggesting an analogy with the anti-Marcos movement in the Philippines.

As the free speech forum developed from an intra-party protest to an anti-Suharto grass-roots movement, the ABRI Headquarters in Cilangkap, East Jakarta, started to view the problem in security terms, warning Megawati supporters to stop the forum. Jakarta Commander, Maj. Gen. Sutiyoso, announced on July 25 that any political action which disturbed law and order would be repressed. The following day, Lt. Gen. Syarwan Hamid-who became Kassospol in February-warned that the forum had already evolved beyond a free speech meeting and was being manipulated by an antigovernment movement. ${ }^{73}$ The next morning around eight hundred governmentsupported Soerjadi cadres and other unidentified men, with the help of security forces (possibly including Brig. Gen. Prabowo's Kopassus personnel in mufti), physically took over the PDI building, sparking a two-day mass riot and clashes with military troops. ${ }^{74}$ Nearly two hundred people were arrested during the first day of the riot, and many of these remain missing. ${ }^{75} \mathrm{~A}$ few days later, Maj. Gen. Sutiyoso issued a "shooton-sight" order to his soldiers.

It was Cilangkap's interest to shift public attention from the Suharto-manipulated Medan Congress to the alleged dalang (masterminds) of the riot. The PRD-an active participant in mimbar bebas-was identified by both Suharto and ABRI as the organization that had planned the riot. The military leadership mobilized its resources to label the PRD as communist, the bette noire of the New Order government, and threatened to investigate any individual or group which had a previous relationship with the PRD activists-a threat which might cover many prominent democratic activists. ${ }^{76}$

To conduct this campaign effectively, sustain high pressure on the anti-regime political movement, and thus insure smooth implementation of the general election in May 1997, the Feisal-Hartono leadership crucially needed ABRI to show solidarity in accepting this interpretation of the PRD, and it needed the support of the Islamic sector. The former attempt to strengthen internal solidarity was made, for example, by

73 "Pangdam Jaya: Ganggu Kamtibnas, Aksi Politik akan Dihentikan," Kompas, July 26, 1996; "Kassospol ABRI: Aksi-aksi Akhir-akhir ini Merupakan Gerakan," Suara Pembaruan, July 26, 1996.

74 For an account suggesting Prabowo's role in the July 27 incident, see, for example, "All Is Not Calm," Time, May 26, 1997.

75 "Pangab: 176 Ditangkap," Harian Terbit, extra-edition, July 28, 1996. According to the final report of Komnas HAM, the riot resulted in five deaths, 149 injured, and 23 missing. For the full Komnas document, entitled "Pernyataan Komnas Mengenai Peristiwa 27 Juli," see Santoso (coordinator), Peristiwa 27 Juli (Jakarta: Institut Studi Arus Informasi and Aliansi Jurnalis Independen, 1997), pp. 59-65. The government banned this book in February 1997.

76 It was considered a major setback for the democratization campaign which had been expanding since the late 1980s, as its advocates' demands were now easily linked with the PRD issue by the government. Prominent democratic activists such as Buyung Nasution and Goenawan Mohammad believed that ABRI could easily arrest them regardless of possible international criticism. Interviews with Buyung Nasution, September 11, 1996; Goenawan Mohammad, December 5, 1996. 
ABRI spokesman, Brig. Gen. Amir Syarifuddin, who appealed to the elite green beret unit (the Army Strategic Reserve Command, or Kostrad) whose participation was significant for any political-security project conducted by ABRI. ${ }^{77} \mathrm{He}$ insisted that it was after the liquidation of Kopkamtib that the communists saw the opportunity to revive their activities in society, and the PRD was the final product. According to him, the PRD should be seen as a communist group because: (1) its manifesto was clearly anti-Pancasila, and its behavior resembled the PKI's attempted coup in Madiun in 1948; (2) its organization was formed in the communist way, by gathering many labor, peasant, artist, student, intellectual organizations, which were often led by ex-PKI figures; and (3) its tactics were communist-oriented because they organized laboragrarian strikes and mass demonstrations in Irian Jaya, West Kalimantan, Ujung Pandang, Bogor, Surabaya, Solo, and Semarang during 1996 with posters demanding "remove dwifungsi." Following the established kewaspadaan doctrine, anti-dwifungsi was dogmatically identified as an expression of communist attitudes. Syarifuddin's clarification was circulated to the territorial commands throughout the archipelago, and those commands were instructed to tighten regional security surveillance in anticipation of counter-actions by the underground members of the ultra-left PRD. ${ }^{78}$

On the other hand, the mobilization of Islamic support for PRD-bashing was attempted as a warning against still-active "atheist" communism. This "theory of contradiction" applied by ABRI was expected to work under the current military leadership which had included top-ranking officers with strong Muslim backgrounds. Among them, Lt. Gen. Syarwan Hamid seemed to be the most active in conducting this operation.

A week before the July 27 riot, Syarwan had a meeting with sixty-one progovernment youth organizations, including many Islam-oriented ones such as MDI (Majelis Dakwah Indonesia) and Pemuda Muslim Indonesia, urging them to watch out for OTB activities and condemning the free-speech forum held by Megawati's wing of the PDI as illegal. These organizations publicly announced their support for the proposal that ABRI take action against the PRD and PDI-Mega. ${ }^{79}$ Also on July 30 , Syarwan held a meeting with a delegation of Islamic youth groups, such as Pemuda Ansor, AMII (Angaktan Muda Islam Indonesia), and Pemuda Tarbiyah. On the next day, they declared their willingness to fight against communism and condemned the PRD as a dangerous element that had instigated the riot. More Muslim organizations, such as Pemuda Muhammadiyah, HMI (Himpunan Mahasiswa Islam), and the government-sponsored MUI (Majelis Ulama Indonesia) also released statements endorsing ABRI's red-purge campaign after the riot. ${ }^{80}$ Furthermore, on August 6, Syarwan had a three-hour talk with the key figures in the United Development Party (PPP)_an Islamic party-regarding the July 27 riot. This was his first meeting with a political party after the riot, indicating the heavy weight put on Muslim organizations in mobilizing support for ABRI's PRD-bashing. The Head of PPP, Ismail Hasan

77 See Amir Syarifuddin (Brigjen: Kapuspen), "Mewaspadai Bangkitnya Kembali Gerakan Komunis di Indonesia," Darma Putra 37 (1996): 24-29. Darma Putra is Kostrad's internal media.

78 Staf Teritorial ABRI, Tinjauan Teritorial (No. Triwulan II, T.A. 1996/1997): 11-19.

79 “Kassospol ABRI: ABRI Minta PDI Hentikan Mimbar Bebas," Kompas, July 21, 1996.

${ }^{80}$ For details, see "Terlalu Naif, Kalau Anggap ABRI Jadikan PRD Sebagai Kambing Hitam," Kompas, August 1, 1996; "Pernyataan Bersama dan Trauma Ormas Islam," Forum Keadilan, August 26, 1996. 
Metareum, expressed his full backing for ABRI's effort. ${ }^{81}$ Finally on August 11, more than ten thousand people from major pro-government mass organizations gathered in Jakarta to release an official declaration of support for the government and urged ABRI to ban the PRD as communist. Syarwan-led ABRI delegates at the meeting insisted that the declaration was spontaneous and not requested by $A B R I$, but emphasized the danger of the communist PRD and the need for promoting close cooperation between ABRI and Islam. ${ }^{82}$ The "contradiction theory" adopted by Cilangkap was aimed at shifting the nature of the political event from an authoritarian crackdown against a popular movement to part of the Islamic struggle against the communist remnants.

In this way, the "Crush PRD-Mega" campaign, which was carried out by Feisal's $A B R I$, heavily relied on the kewaspadaan approach established under the previous military empire of Gen Murdani-with fine adjustments of its definition of the threat and the target population for counter-mobilization. Although the color of the two leaderships was very different, and each was antagonistic to the other, the institutional inertia was at work rationalizing ham-fisted and praetorian military intervention in politics.

This continuity was rooted in the developmentalist ideology of the New Order military which viewed economic modernization as indisputably beneficial to the national interest and the military's "permanent" political commitment as an effective measure for insuring the preconditions to achieve modernization. This ideology necessitated the invention of discursive techniques to produce "national" threats which required ABRI to provide its "professional service" to eliminate them. Routinization of this ideological activity was the role of Lemhannas, and both Soebiyakto and Hartono-two very different figures-contributed in similar ways to this organizational task. The former completed the standard material for Balatkom and also proliferated the concept of fourth-generation communism, while the latter invented a theory which made the popular democratic movement a "legitimate" object of the kewaspadaan approach, by infusing the idea of globalization-which was interpreted as the primary source of ideological deviation in society-into its doctrine. This theory "freed" ABRI to identify the movement as inspired by communism although it did not present communist ideology, because the penetration of foreign values in the era of globalization allegedly allowed ideology to enter Indonesia in various forms. This thinking justified the argument that once the movement displayed methods resembling those of the communists, it could be identified as communist, so that it became a legitimate target for military operations mobilized to ensure political stability for economic development. In the repression of the PRD, this legitimation was applied. ${ }^{83}$ These ideas were, of course, not fully accepted by society; many critics thought $A B R I$ was becoming increasingly rigid and dogmatic in response to growing

81 "Syarwan: Kita Sudah Ingatkan Tetapi Dituduh Mengada-ada," Suara Pembaruan, August 7, 1996.

82 "Apel Kebulatan Tekad Dukung Orde Baru," Suara Pembaruan, August 12, 1996, and personal communication with an anonymous journalist who attended the meeting, August 1996.

83 In celebrating Pancasila day on October 1, 1996, Jakarta's main street (Jalan Sudirman) was decorated with large colorful posters warning of Bahaya Laten Komunisme. The posters presented a chronological portrait of alleged communist insurgencies; Madiun 1948, G30S/PKI 1965, and PRD 27 Juli 1996. Note that the posters put the PRD next to the 1965 event, deliberately omitting other cases during the last thirty years, which had been claimed by ABRI as communist-led events. This was meant to suggest that the current issue was as serious as the attempted coup in 1965. 
democratic demands. For the military leadership under Feisal and Hartono, however, the effort could be justified as consistent with ABRI's long-run institutional activity to reproduce the legitimacy of developmentalist ideology, which had faced a serious challenge since the loss of USSR - the principal source of Balatkom legitimation.

\section{The Loss of Military Cohesion and the Rise of Dissent}

Whether or not the adapted kewaspadaan approach in the mid-1990s was a sign of ideological cohesion among the officer corps was, however, a different question. As discussed earlier, the transformation of Suharto-ABRI relations after the fall of Murdani produced issues which could accentuate cleavages within the military-for instance, the question of ABRI's autonomy vis-à-vis Suharto, the rise of Prabowo, links to ICMI, the mobilization of Islamic issues in conducting military policies, and dogmatization of the military response to popular movements. Although the promulgation and evolution of kewaspadaan ideology was a element in the "corporate" interests of the military as a whole, this did not mean that implementation measures were unquestioned and always welcomed by the officer corps at large. The development of intra-military cleavages created by these issues contributed to the rise of reform-minded officers who were concerned about the direction of the FeisalHartono leadership. Since any military organization respects discipline and command, as a part of professionalism, it is difficult to find public statements by serving officers about internal problems-such statements would no doubt put their careers at risk. But their voices were represented by retired generals who had became increasingly critical in the public arena as they perceived the military leadership failing to address the dissatisfaction of many of its officers. Such developments during the final years of the Suharto polity facilitated the perception that reshaping the role of the military in political life-reconsidering President-ABRI relations, Golkar-ABRI relations, and more generally society-ABRI relations-was crucial to prevent ABRI's further loss of social trust. This perception was also reflected in the kewaspadaan thinking. Let us examine the development of internal military cleavages during the Feisal-Hartono leadership since February 1995, and the rise of revisionist thinking within ABRI.

\section{The ABRI-Golkar-ICMI Axis: Nationalism and Neutrality in Question}

The first major event was ABRI's rapprochement with Golkar in mid-1995. As discussed before, Feisal Tanjung had cooperated with Suharto and Habibie in naming a civilian, Harmoko, for the first time to be Golkar chairman in 1993. It was in September 1995 that Cilangkap, in preparing for the 1997 general election, again showed its overt support for Golkar under Harmoko; at this time Maj. Gen. Syarwan Hamid insisted that ABRI could not be neutral in politics because ABRI as a sociopolitical force needed to choose a partner to promote national well-being, and for this reason, ABRI would act in alliance with Golkar. ${ }^{84}$ Five days later, Kapuspen Brig.

84 “ABRI Tidak Bisa Netral Sebagai Kekuatan Sospol," Kompas, September 30, 1995. Syarwan was Assospol Kassospol at that time. He had occupied this position since June 1995. His predecessor, Maj. Gen. Hari Sabarno, was then appointed to F-ABRI together with Maj. Gen. Haris Sudarno, East Java Kodam Commander and Maj. Gen. Theo Syafei, the Commander of ABRI's Staff and Command College 
Gen. Suwarno Adiwijoyo, who inherited this post from Syarwan the previous March, asserted that: "if ABRI is asked to be neutral, it would mean that ABRI should abandon its principles [to maintain stability] and that is impossible." 85 These public statements soon invited intense public criticism because they were seen as contradicting ABRI's role as "national" guardian. ${ }^{86}$ As the critical mood spread in society, Pangab Feisal Tanjung asserted that there was no political activity without partnership; thus "ABRIGolkar" was practical from this perspective. ${ }^{87}$

The escalation of public debate about ABRI's overt rapprochement with Golkar was followed by the establishment of a group that declared its concern about the sectarian tendency of national politics under the growing influence of ICMI. On October 23, Lt. Gen. Bambang Triantoro, former Kassospol (1985-7) under Murdani, announced the creation of a new political association, the Foundation for National Brotherhood Harmony (YKPK); in his capacity as its general chairman, he explained at a press conference that his actions were motivated by growing concerns about national unity and integration. This sixty-eight-member group attracted much attention in political society, partly because it was seen as opposed to the sectarian ICMI and partly due to its high-profile participants. ${ }^{88}$ The establishment of YKPK was of course welcomed by secular-minded military officers, with Gen. Edi Sudradjat describing it as "excellent because they are very much concerned with building up the national spirit." 89 It was also publicly endorsed by the Speaker of Parliament, Lt. Gen. (ret) Wahono, the Minister of Transmigration Siswono, and the Minister of the Environment Sarwono, who were all commonly regarded as being in the "nationalist" camp within the Cabinet. Equally interesting was the emerging prominence of retired generals who

(DanSesko ABRI). Haris was replaced by Maj. Gen. Imam Utomo, a close ally of Hartono, while Theo's post was taken by Maj. Gen. Yunus Yosfiah, an officer close to Feisal. Theo, a Protestant officer, had close links with former Defense Minister Benny Murdani and Edi Sudradjat, and was therefore a target of Feisal and Hartono who were installed in the ABRI leadership as a part of Suharto's de-Murdani-zation program.

85 "ABRI tak Berprinsip Jika Netral," Kompas, October 4, 1995.

86 For example, Subagyo from the PDI stated at the DPR that Syarwan's comment would not only confuse people, but also invite social unrest ("Aspirasi Politik Keluarga Besar ABRI Tetap ke Golkar," Suara Merdeka, October 4, 1995). Matori Abdul Djalil, the former secretary-general of the PPP, insisted that ABRI would lose its credibility if it sided with Golkar, since all political parties already accepted Pancasila as their sole principle in the mid-1980s, so there was no reason for ABRI to choose a partner ("Langkah Mundur Jika ABRI Tetap Memihak Golkar," Bernas, October 1, 1995). Retired Lt. Gen. Kemal Idris, the former Kostrad Commander who is widely regarded as one of the founders of the New Order in the mid1960s, argued that Syarwan's comment illustrated the arrogance of power which made power-holders believe "I can do no wrong" ("Kemal Idris: ABRI Terlalu Terlibat di Segala Bidang," Forum Keadilan, October 23, 1995). Media criticism of Syarwan was also strong as seen in Suara Merdeka (October 1, 1995), Jakarta Post (October 6, 1995) and Kompas's four long articles on this issue (October 5, 1995).

87 "Feisal Tanjung: Dwifungsi Lestari Sepanjang Masa," Forum Keadilan, October 23, 1995.

88 They included, for example, Lt. Gen. (ret) Kharis Suhud (former Chair of MPR/DPR 1988-1993), Maj. Gen. (ret) Samsuddin (former Head of F-ABRI), Gaffar Rachman (former Secretary General of Nahdlatul Ulama, or NU, the biggest Islamic organization in Indonesia), Hasjim Wahid (brother of Abdurrahman Wahid, the NU Chairman, who had criticized ICMI as a sectarian group), Marzuki Darusman (former Golkar politician now Deputy Chairman of Komnas HAM), and Kwik Kian Gie (prominent Chinese economist affiliated with the PDI). Because of the various backgrounds of its members, the group was called the "rainbow alliance" (aliansi pelangi).

89 "Menhankam: YKPK Sudah Lama Dinanti," Kompas, October 25, 1995. 
had been associated with the military leadership under Murdani and become critical to Suharto-and ABRI under Feisal Tanjung-in the age of keterbukaan. The presence of these discontented officers, such as Lt. Gen. (ret) Bambang Triantoro, Lt. Gen. (ret) Kharis Suhud and Maj. Gen. (ret) Samsuddin, significantly boosted the political role of recently retired officers in the public arena. They effectively replaced, as vocal critics, the group of officers, from the revolutionary generation, that had come together in 1980 and promulgated the Petition of 50 (Petisi 50). That group had been the subject of severe pressure from ABRI's during the Murdani era. ${ }^{90}$

Moreover, Edi Sudradjat's endorsement of YKPK reflected his nationalist concerns, which he had repeatedly expressed during that year. Three times during the preceding three months Edi had stressed the need for strengthening nationalism within ABRI, thus demonstrating his concerns about the sectarian tendencies within the military and its overt alliance with one particular political party. In July and again in August 1995, Edi warned that ABRI was now thought of as a "tool of the rich" given the reality that some ABRI members had close ties with business tycoons and therefore conveyed the impression that ABRI was not above manipulation..$^{91}$ Also on September 8, addressing an ABRI Seminar in the Armed Forces' Staff and Command College (Sesko ABRI), Bandung, Edi reiterated the need to cleanse ABRI and set it above suspicion in both the economic and political fields. ${ }^{22}$ Edi's demand for housecleaning and heavy emphasis on nationalism and probity apparently signaled his displeasure with the current leadership style in ABRI.

The Islamization of the ABRI leadership had been strengthened after Hartono's promotion to Army Chief in February 1995, an action that in turn established the "Feisal-Hartono duet" with the blessing of ICMI. After the launching of YKPK, with its counter-emphasis on nationalism unaffiliated with a particular religion, officers' concerns about sectarian politics intensified and became somewhat more visible. ${ }^{93}$ Interestingly, Golkar members who joined YKPK were apparently among those marginalized by Harmoko due to their closeness to former Golkar chairman, Wahono. Of course in public, YKPK Chairman Bambang Triantoro denied that he intended to

\footnotetext{
90 Petisi 50 consisted of fifty retired officers and civilian intellectuals, and was launched in response to Suharto's speech at Pekanbaru which said that ABRI would continuously support Golkar in the next election in 1982. Gen. (ret) Abdul Haris Nasution, former Army Chief of Staff before the New Order (194952, 1955-62) and Admiral (ret) Ali Sadikin, the popular ex-Governor of Jakarta, were the leading figures in this group. From the time of its foundation, they openly criticized ABRI's overt support for Golkar, and insisted that it deviated from ABRI's designated political role as originally intended and designed by the officers of the revolutionary generation. For a discussion of Petisi 50 and ABRI's pressure on them, see David Jenkins, Suharto and His Generals: Indonesian Military Politics 1975-1983 (Ithaca: Cornell Modern Indonesia Project, Cornell University, 1984), pp. 171-187. Although the ICMI factor significantly influenced the establishment of YKPK, the real trigger to action was again the ABRI-Golkar issue, as it was in the case of Petisi 50. This shows how this issue provided significant momentum for the development of elite opposition during the New Order. YKPK was accepted by Petisi 50 as a good partner that shared many of its own political visions (interview with Ali Sadikin, July 30, 1996).

91 "Kredibilitas ABRI Tergantung Sikap ABRI Sendiri," Kompas, July 21, 1995; “ABRI: Berdagang, Jangan Berdagang," Forum Keadilan, August 28, 1995. Golkar had been backed by many business tycoons, including members of the Suharto family.

92 "ABRI Harus Bersih dan Berwibawa," Bernas, September 9, 1995.

93 For the social backgrounds of YKPK members, see "Profile YKPK: Merah, Kuning, Hijau, di Langit YKPK," Tiras, November 2, 1995.
} 
try and curb the runaway influence of Habibie and ICMI, but in an interview he admitted that his sixty-eight-member group shared the thinking of Gen. (ret) Murdani-a leading anti-ICMI figure-though he was not involved directly in the establishment of YKPK. ${ }^{94}$

Bambang's movement, which was endorsed by Edi and "shared" by Murdani, met with a negative response from Syarwan Hamid. When asked about ABRI's perception of ICMI, he said that many in ABRI hoped that ICMI could bring Muslims-who comprised 88 percent of the Indonesian population-into the mainstream of national development. At the same time, in replying to a question about the emergence of YKPK, which enjoyed support from a group within ABRI, Syarwan warned that if it did not contribute to the national interest, the system would ostracize it and cause it to fade away before it could develop. ${ }^{95}$ Syarwan's essentially positive reaction to ICMI and negative assessment of YKPK differed from the reactions of the Defense Minister, who saw the establishment of YKPK as fulfilling a "need" to deepen national comprehension of the Archipelagic Concept, or Wawasan Nusantara, which respected national integration rather than group interests. According to Edi Sudradjat, Wawasan Nusantara was of the utmost value, but was now threatened due to the maneuvering of certain interest groups. ${ }^{96}$ An attempt by the ABRI leadership to stifle YKPK occurred in connection with the First National YKPK Discussion held in Surabaya on January 8-9 in 1996, with the opening ceremony chaired by Wahono. Maj. Gen. Iman Utomo, a close ally of Hartono, who had commanded the East Java Kodam, appealed to his soldiers, veterans, and Golkar members not to attend the discussion. All this showed that the emergence of YKPK reflected different perceptions and policy stances within ABRI, especially between the heads of two organizations, ABRI itself and the Defense Ministry. What's more, these differences in attitude were basically rooted in their contrasting views on, and links with, ICMI.

The two issues discussed above, i.e. neutrality and sectarian problems, figured as major themes in this ongoing debate as ABRI moved closer to Golkar. The rejection of neutrality by Syarwan and Feisal reinvigorated a long-standing debate on the legitimacy of ABRI's involvement in national politics. Moreover, a concern for the sectarian resurgence-which is examined here as the second dimension of ABRI's approach to Golkar-led to the formation of a new political movement countering ICMI's growing influence. Both provided perfect opportunities to expand political space for retired officers who became highly assertive in the debate about the ABRI problem.

The divergence in perceptions between the Defense Minister, on the one hand, and the ICMI-aligned ABRI Commander and Army Chief of Staff, on the other hand, became increasingly apparent from early 1995. Soon after, signs of another gap appeared, this time between the ABRI Commander and the Army Chief. In March 1996, when addressing a Golkar meeting in Central Java, where Siti Hardijanti

94 "New Group to Counter Habibie Influence," Reuters, October 25, 1995. Bambang explained that both he and Murdani were concerned about some groups in the regime that put religious interests before national interests. Interview, 16 December 1996.

95 "Mayjen Syarwan Hamid: Yang tak Bermanfaat akan Layu Sebelum Berkembang, Republika, December 9, 1995.

96 See his interview in "Ini Kan Suatu Kebutuhan," Tiras, November 2, 1995. 
Rukmana, or Tutut, the President's oldest daughter and a Chairperson of Golkar's Central Leadership Council, was also present, Hartono made a controversial statement in front of five thousand Golkar cadres. He said: ". . . every ABRI member is a cadre of Golkar and there is no need for them to be dubious about stating their allegiance to Golkar." Showering praise on Mbak Tutut, he went on to say that: "as a Golkar cadre, my duty is to receive advice and instruction from Mbak (sister) Tutut." 97 Next day, on March 14, at the Sabilil Muttaqien Pesantren (Islamic School) in Magetan, East Java, this former Commander of East Java again expounded his theory of ABRI-Golkar relations. After a speech by Tutut, Hartono-who was wearing a Golkar yellow jacket-declared in front of Golkar supporters that "Kodim (Military District Command) commanders and regional police chiefs are members of Golkar's regional advisory council, which means that all their staff are also Golkar members." Since not only local commanders, but even Pangab Feisal Tanjung was a member of the Supervisors' Council, he concluded that all ABRI members were in fact Golkar cadres. ${ }^{98}$

Although ABRI leaders had often pointed out that ABRI had established Golkar, Hartono's remarkable statement was the first in which a high-ranking military officer had described ABRI's subordination to Golkar in such an explicit way. ${ }^{99}$ This reinterpretation of Golkar-ABRI relations was quickly corrected by the Cilangkap circle in the following days, indicating that Hartono had overstepped ABRI's standard civilmilitary theory, and also exceeded his capacity as Army Chief by talking as if he represented all four services within ABRI. The next day Feisal Tanjung explained that ABRI members who joined Golkar did so to "supervise" it, meaning he rejected Hartono's view of ABRI's subordination to the political party. ${ }^{100}$ Then, Syarwan Hamid made an official announcement, saying that Hartono's statement was made in his personal capacity, not as Army Chief. ${ }^{101}$ Such dissociation from Hartono's statement that "ABRI members are Golkar's cadre from Pangab to Kodim" gave rise to the gap between the Habibie-Harmoko-Feisal-Syarwan line and the Tutut-Hartono line.

This disagreement between the two ICMI-affiliated generals-i.e. Feisal and Hartono-was relatively insignificant for non-ICMI figures who now learned that the current military leadership did not hesitate to declare that ABRI, in its entirety, overtly allied itself with a single political party (though at the same time the ICMI-affiliated generals denied that ABRI was subordinate to Golkar). These reports soon alarmed the Defense Minister. When asked about Hartono's controversial statement and the subsequent explanation by Syarwan Hamid, Edi Sudradjat signaled his disagreement

97 "KSAD: Setiap Anggota Abri Kader Golkar," Kompas, March 14, 1995. Officially Tutut was only one of eight chairpersons under General Chairperson Harmoko. Thus Hartono's statement, which bypassed Harmoko in declaring the fusion of ABRI-Golkar, could also be understood as a statement of his personal loyalty to Tutut.

98 "Hartono: Frivolous Questions About Golkar Allegiances Cause of Concern," Kompas Online, available HTTP: <http://www.kompas.com/>, March 15, 1996.

${ }^{99}$ Gen. (ret) Benny Murdani, for example, argued that "Hartono's way [of approaching Golkar] is too overt. ABRI's support for Golkar should not be done in such an open way." Interview, March 4, 1997.

100 "Feisal Tanjung: ABRI Tetap ABRI," Kompas, March 16, 1996.

101 "ABRI Sebagai Kekuatan Sospol dan Hankam," Suara Pembaruan, March 18, 1996. 
by saying that $A B R I$ should work with other parties and not just Golkar to help develop the nation. ${ }^{102}$ Referring to Law No. 20, created in 1982, which stipulated that all parts of ABRI must work together with all sociopolitical forces to insure national development, Edi stressed the supremacy of the law over any other considerations. ${ }^{103}$ Several retired generals and civilian leaders supported Edi's criticisms. For example, Lt. Gen. (ret) Hasnan Habib argued that: "if ABRI sides with one group, it does not need F-ABRI any more." "Law No. 20/1982," Hasnan continued, "neither allows civilian nor military supremacy, so ABRI can never be a cadre of the civilian Golkar."104 A YKPK activist, Maj. Gen. (ret) Samsuddin, also stressed the inconsistency of the Feisal/Hartono approach with ABRI's official doctrine, by maintaining that ABRI's triple commitment-to Pancasila, the Constitution and the "people's security and prosperity" -was the basis of ABRI's political role, and these commitments prevented ABRI from siding with any one group, no matter what it was. ${ }^{105}$ Criticisms were also aired in the PDI which had actually experienced ABRI's heavy intervention in its East Java Chapter in matters having to do with the leadership split between proand anti-Megawati factions. PDI legislator Marcel Beding voiced concern that if Hartono's statement became official policy, a whole range of political laws would have to be overhauled, and F-ABRI would have to be scrapped, because ABRI would be able to channel its aspirations through Golkar. Sophan Sophian of the PDI added that if Hartono's view prevailed, the PDI would withdraw its support for ABRI's dwifungsi. ${ }^{106}$ The Petisi 50 soon sent a letter to the DPR, saying that Hartono's stance contradicted the spirit of ABRI as codified in Sapta Marga and Sumpah Prajurit, and asking that the DPR demand that Suharto review Hartono's position as Army Chief. 107

ABRI's move toward Golkar in 1995-6 reflected its determination to acquiesce in Suharto's political program involving Golkar-ABRI cooperation to insure that the coming general election would run smoothly and predictably so as to secure his presidential re-election in 1998. However, ABRI's pursuit of this Suharto project, led by Feisal, Syarwan, and Hartono, invited at least three consequences: (1) it exacerbated the split within the elite (namely between ICMI and secular-nationalist camps); (2) it exposed the cleavage within the military leadership-respectively between Feisal and Hartono, who had different partners within Golkar, and between them and Edi Sudradjat; and (3) it reinforced ABRI's public image as a mere tool of Suharto's private interests. All of these consequences resulted in an increase in the number of active critics-especially retired officers, students, intellectuals-who publicly accused the military leadership of policy deviations. When ABRI leaders faced this deepening and

\footnotetext{
102 "ABRI tidak Hanya Berjuang dengan Golkar," Suara Pembaruan, March 25, 1996.

103 Edi's comment, however, should be interpreted in the context of a power struggle with the pro-ICMI forces, rather than as a simple legal argument. Note that he had suggested the nomination of ABRI candidates for the position of the Golkar Chairman in 1993, which would work to secure ABRI's influence in Golkar.

104 "Sekadar Menghebohkan Hubungan ABRI-Golkar," Forum Keadilan, April 8, 1996.

105 Ibid.

106 "Army Stance on Golkar Draws Fire," Jakarta Post, March 15, 1996.

107 "Petisi 50 Menggugat Hartono," Indonesia-L (Online Mailing List), Available E-mail: <apakabar@clark.net>, March 26, 1996. Literally, "Sapta Marga" is ABRI's "Seven Pledges" to dedicate itself for the national interest, and "Sumpah Prajurit" is the "Soldiers' Oath." Both outline ABRI's traditional organizational values.
} 
110 Jun Honna

widening criticism, the dogmatic quality of their response to opposition became apparent. It was in this political context that the characteristics of kewaspadaan political programs during that time-for instance, the OTB campaign and the red-purge of PRD-largely reflected the nature of the military leadership which had been formed to secure Suharto's political base in the post-Murdani period since 1993. 108

\section{Prominence of Retired Officers}

The inclination toward dogmatization and the declining cohesion within the military were further exacerbated in 1996, following the toppling of Megawati from the PDI and the launching of a security operation to crush the PRD, the hantu PKI (PKI ghost). A few days after the Medan congress, Defense Minister Edi Sudradjat claimed that national stability could never be built on authoritarianism. Also a day after the three-day riot in Jakarta, the Speaker of Parliament, Lt. Gen. (ret) Wahono, asserted that ABRI should limit its repressive behavior because it could only succeed in its political role when it had public support. Former Army Chief, Gen. (ret) Rudini, further insisted that the time had passed when ABRI could invoke the specter of communism to justify repressive measures, and ABRI-if it wanted to do so-had to show strong evidence to support its accusations. Otherwise, he said that ABRI and the government would lose the people's trust. ${ }^{109}$ Criticism from retired officers grew louder as repression and the red-purge continued.

Responding to this, Suharto was said to have complained that retired officers often voiced ideas opposing Pancasila and the 1945 Constitution, and that they made statements which were not consistent with their actions and views when they were on active duty. ${ }^{110}$ It was Edi Sudradjat who first responded to Suharto's reported remarks by insisting on the need for constructive criticism from retired officers to fertilize democracy, whereas Lt. Gen. (ret) Solichin GP, former Governor of Akabri (Military Academy) during 1968-70, defended outspoken figures such as Bambang Triantoro, Kharis Suhud, and A. H. Nasution by saying, " . . they criticize for the well-being of the nation, so the regime should not consider those who criticize as the enemy; it will be a loss for everyone in the country." Nasution himself insisted that if one was still committed to Pancasila and the Constitution, being critical was quite logical. ${ }^{111}$

108 Recalling the series of events in 1996, Gen. (ret) Abdul Haris Nasution expressed his concern that, "ABRI's current political activities are all conducted in the interests of the President to an unprecedented degree." Written interview, January 4, 1997.

109 Above comments are from "Menhankam: Stabilitas Nasional tak Dibangun di Atas Kekuasan yang Otoriter," Kompas, July 6, 1996; "Ketua DPR/MPR: ABRI Harus Kurangi Reaksi-reaksi Represif," Kompas, August 1, 1996; and "Rudini: Semua Pihak Harus Menahan Diri," Kompas, August 2, 1996.

110 Suharto's comment was not announced by himself, but through Tantyo AP Sudharmono, son-in-law of former vice president Sudharmono and the head of the youth wing of the MKGR, one of three founding organizations of Golkar, who had just had a meeting with Suharto and quoted his words at a press conference. However, those who know Suharto questioned the credibility of Tantyo's comment. Murdani, for example, argued that "such a comment could never come from Suharto because it was totally against his political style." Interview, September 23, 1996.

111 For above comments, see "Criticism from Retired Officials Needed, Edi Says," Jakarta Post, September 13, 1996; "Letjen TNI (Purn) Solichin GP: Sikap Kritis Semata-mata Membantu," Kompas, September 25, 1996; "AH Nasution: Ketidakadilan Sosial Musuh Paling Besar," Suara Pembaruan, September 28, 1996. 
In response, the Coordinating Minister for Political and Security Affairs (Menko Polkam), Lt. Gen. (ret) Soesilo Sudarman, who also headed Pepabri (the Association of Retired Officers), supported Suharto's remarks by maintaining that some retired officers were behaving inconsistently. Admiral (ret) Sudomo also showed his annoyance, saying, ". . . if retired generals want to correct the nation and its development, they should direct their views to the president rather than advertise problems in the mass media, as I have suggested to Petisi 50." ABRI Commander Feisal Tanjung echoed this stance toward outspoken retirees. Recalling the July 27 riot, he claimed that the real problem arose from the ideological distortion generated by the socalled "rainbow alliance" (aliansi pelangi), with the communist PRD as its rising star. He then blamed recent political-security worries on the PRD which he branded as radical and anti-New Order-ABRI; thus he concluded, in a dogmatic way, that the "rainbow alliance" group was trying to replace Pancasila and the Constitution. He stated that this undesirable political situation was facilitated by individual retired officers and asserted that these officers deviated from military discipline and acted disloyally. ${ }^{112}$

Feisal's remarks stirred up harsh reactions from retired officers. ${ }^{113}$ As if challenging Feisal, they became more assertive in criticizing ABRI's political role, not only in the media but particularly at ABRI's internal meetings. In early September, the 1996 ABRI Seminar was held. The seminar was designed by Cilangkap to solicit advice from several experts regarding ABRI's policy preparation for the Seventh Development Cabinet starting from 1998. Lt. Gen. (ret) Hasnan Habib objected to a statement written in ABRI's draft paper for the Broad Outlines of the Nation's Direction (GBHN) and requested its revision. Pointing to the original statement that said that the emerging criticism of ABRI's political role was caused by a wrong assessment that identified civilian and military jobs in a dichotomous way, Hasnan asserted that the real reason was not the dichotomy, but rather ABRI's obvious domination of national life, which restricted people's political participation. Furthermore, objecting to a section that claimed that Pancasila ideology was now threatened by communism, he contended that the threat was rather due to the government's arbitrary interpretation of Pancasila; in saying this, he rejected the kewaspadaan approach adopted by the Feisal-Hartono leadership. ${ }^{114}$

112 Quotations are from "Di Depan Presiden Soeharto, Soesilo Akui Ada Purnawirawan Kurang Konsisten," Republika, September 26, 1996; "Ketua DPR Sudomo: Bila Ingin Melakukan Koreksi, Lebih Baik Langsung ke Presiden," Kompas, September 26, 1996; "Pangab, Soal Purnawirawan tak Konsisten: Mereka Ekstradisiplin dan kontraloyalitas," Republika, September 27, 1996. Feisal, however, did not identify the retired officers.

${ }^{113}$ For special coverage on this, see "Aksi dan Reaksi Para Mantan Jenderal," Forum Keadilan, October 7, 1996, and "Tuding-menuding Siapa yang Tidak Konsekuen Melaksanakan UUD 45 dan Pancasila," Swadesi, October 4-10, 1996. For the next few months, interviews with outspoken retired generals-who all condemned Feisal's statement-appeared in the media. A tendency for generals to become more vocal in their criticism following reitirement can be explained by one (or a mix) of the following reasons: that as nationalist officers they value the army's popular origins in the independence war, but only feel free to express this allegiance after their term of forced loyalty to the government has ended; that it comes from opportunism; that it is a sign of dissatisfaction from officers who were not offered better post-service jobs.

${ }^{114}$ Hasnan Habib, "Pembangunan Nasional Bidang Hankam Pada Pelita-VII (Tanggapan)," paper prepared for Naskah Makalah Awal "Pokok-Pokok Pikiran ABRI Tentang Pembangunan Nasional Pada Pelita-VII," Seminar ABRI, Mabes ABRI, Jakarta, September 3, 1996. 
112 Jun Honna

Two months later, Sesko ABRI held a seminar, entitled "Actualization of ABRI's Sociopolitical Role," to which noted retired officers and civilian intellectuals were invited. Gen. (ret) Rudini on this occasion claimed that the concept of ABRI's political role should be revised to cope with new social developments. ${ }^{115}$ Lt. Gen. (ret) Harsudiono Hartas-former Kassospol who declared the nomination of Try Sutrisno as vice president in 1993-also argued that ABRI now deviated from its ideal. If such deviation continued, he concluded, it might also undermine ABRI's traditional, valued role as a force of "freedom-fighters." 116

On the same day as the Sesko ABRI seminar, the Army Staff and Command College (Seskoad) in Bandung also held a panel discussion on ABRI's political role. One of the panelists, Maj. Gen. (ret) Zein A. Maulani, presented a critical approach to the current military leadership. He argued that ABRI's political role should be redefined because the task of protecting national stability could no longer be monopolized by the military in the present stable conditions. Moreover, he criticized the influence of business-capitalist groups in ABRI, noting those times when in land conflicts and industrial relations ABRI had sided with capitalist groups. He warned that the coalition between $A B R I$ and various business and conglomerate interests had brought the army far from its original ideals and undermined popular acceptance of ABRI's political involvement. ${ }^{117}$

Judging from the patterns of previous debates, one can guess that if these arguments by Hasnan, Rudini, Hartas, and Maulani had been offered by civilian critics and NGOs rather than by officers, ABRI might well have accused the critics of being too Westernized, of ignoring history, or possibly of being anti-dwifungsi and thus antiPancasila and subversive. Responding to the intensive criticism at ABRI-sponsored seminars, Feisal Tanjung merely claimed that it was an irony of dwifungsi that its success invited criticism. ${ }^{118}$ Retired generals-who had contributed to the building of the New Order and then retired in the age of keterbukaan-played important roles both in countering the growing dogmatism of the ABRI leadership and, significantly, in providing intra-military communication space for revisionist views among the active officer corps, especially for those who were concerned about declining military credibility in society and the ongoing power struggle within the command resulting

115 Rudini, "Legitimasi Sosial Peran Sospol ABRI," paper presented at Sarasehan Sesko ABRI Tentang Aktualisasi Peranan Sospol ABRI, Sesko ABRI, Bandung, November 4-5, 1996.

116 "Penerapan Dwifungsi ABRI Masih Sering Menyimpang," Kompas, November 5, 1996. The freedomfighter refers to the role played by the military during the independence war. It is a symbol of ABRI's nationalist orientation.

117 See Z. A. Maulani, "Implementasi Fungsi Sospol ABRI pada Masa Kini dan Masa yang Akan Datang," paper presented at the panel discussion, Forum Kajian Dwifungsi ABRI, Seskoad, Bandung, November 5, 1996. Maulani was Habibie's adviser for military affairs at that time. He was a classmate and friend of Feisal Tanjung, and commanded the Kalimantan Kodam during the period of 1988 to April 1991. He was one of the most successful officers to emerge from the class of 1961 at the military academy, but his career was stopped by Defense Minister Murdani in 1991 allegedly due to Murdani's unhappiness with Maulani's Islamic orientation and sympathetic attitude toward Petisi 50. He then became Secretary General of the Department of Transmigration, and was later recruited by Habibie as his advisor. His criticism cited above, however, represented a common perception in society and did not coincide very well with the interests of Habibie who owned big businesses.

118 "Pangab Tentang Dwifungsi: ABRI Dipaksa Tanggung Beban dari Keberhasilannya Sendiri," Kompas, November 23, 1996. 
from Suharto's patrimonial recruitment of loyalist officers to the top military positions. ${ }^{119}$

\section{Concerns of Serving Officers}

In private, a serving brigadier general in Cilangkap argued that: "many of us are concerned about today's political role of ABRI which is being used only to support Pak Harto [Suharto]. Who will pay the price of being unpopular among the rakyat [people]? It is the next generation officers who will inherit the leadership in the near future."120 In intra-military communication, however, criticism was muted, since expressing internal criticisms openly would put the officers' careers at risk. Thus the wording of public criticism was cautious. Even so, several concerns could be identified in officers' internal writings. ${ }^{121}$

119 After the July 27 riots, personnel transfers were conducted in August 1996, which affected more than a hundred officers and contradicted Feisal's announcement in February that there would be no major reshuffles until the general election in 1997. Among others, Brig. Gen. Bambang Yudhoyono (Chief of Kodam Jaya [Jakarta]) moved to the post of Kodam Commander in South Sumatera, with his promotion to two-star general. As the top graduate of Akabri in 1973, he was reputed to be a leading intellectual officer of the next generation in ABRI. Bambang's previous post was then filled by Brig. Gen. Syafrie

Syamusoeddin, a classmate (Akabri 1974) and close associate of Prabowo. Soon after the August transfers, Hartono's proposal to restructure Kopassus so that it was made up of five divisions rather than just three divisions was implemented, allowing the commander's post to be filled by a Maj. Gen. Brig. Gen. Prabowo was therefore automatically promoted to two-star general. A series of rotations in the last few years had generated a concern about the growing instability of career paths. Maj. Gen. (ret) Z. A. Maulani claimed that the pace of transfer was abnormal. See his "Regenerasi ABRI 1995-1996," Profile Indonesia (Jurnal Tahunan CIDES, No. 2, 1996): 139. Maj. Gen. Theo Syafei of F-ABRI openly addressed this issue. At a DPR meeting in March, this anti-ICMI general pointed out the growing distortion in current personnel management caused by political influence; he was referring to Suharto's political maneuverings, which had placed loyal officers in top military posts. Although politics had always influenced promotions, Theo insisted that the recent reshuffling especially resulted in the "inflation of generals" (inflasi jenderal) and a shortage in the number of posts available for general-ranking officers. Edi Sudradjat responded to Syafei by saying that the question now was whether the pace of transfer was too fast or not, admitting the problem in personnel management. See "Bila Gerbong Mutasi Macet di Atas," Forum Keadilan, March 25, 1996 and "Pangab Mengenai Tiga Letjen tak Punya Jabatan," Kompas, March 6, 1996. For an account of the reshuffling that focuses on structural factors, particularly high recruitment to the military academy in the 1960s and early 1970s, rather than political ones, see The Editors, "The Indonesian Military in the Mid1990s: Political Maneuvering or Structural Change," Indonesia 63 (April 1997): 91-105.

${ }^{120}$ Confidential interview, December 1996.

${ }^{121} \mathrm{I}$ am indebted to a retired officer who suggested to me the importance of understanding kromo in officers' writings, as a technique to "read words" behind the established formal rhetoric. Kromo, or krama, is the Javanese language form characterized by politeness, officiality and formality which was used by priyayis (indigenous civil servants) during the colonial period. Opposite to krama is ngoko which represents the informality, proximity, and emotionality used in daily social conversations. Anderson describes krama as like a mask whereas ngoko is like the heart. See Benedict Anderson, Language and Power: Exploring Political Cultures in Indonesia (Ithaca: Cornell University Press, 1990), pp. 131-132. Apart from cultural habit, there seem to be two practical factors which push serving officers to use formal rhetoric in articles they publish in ABRI journals. First, journals like Ketahanan Nasional of Lemhannas and Yudhagama of Army Headquarters are the arenas in which many officers hope to demonstrate their level of mental discipline and their conformity to the ideology promulgated by the military's education program, since these educators have influence in determining promotion. Second, these journals make it clear that editors reserve the right to edit submitted papers without obtaining the permission of the authors in order to 
114 Jun Honna

For example, in mid-1995, Maj. Gen. Hari Sabarno, in his graduation thesis at Lemhannas, wrote that ABRI's support for Golkar should be reviewed to make ABRI more neutral in dealing with all political forces. ${ }^{122}$ The problem of personnel management was also discussed. Syarwan's assistant, Maj. Gen. Suwarno Adiwijoyo (Assospol Kassospol) expressed a concern about the officers' growing uncertainty regarding their tours-of-duty, especially at the top level of the army. "After getting a new position, a general needs at least one year to settle into the position and should not be replaced in a haphazard way at least during the five-year cycle of one ABRI Commander." He believed that this pattern had been distorted by promotional decisions which were influenced by politics and favoritism and which had increased dissatisfaction among ordinary officers. Suwarno stressed that the job criteria should be codified more clearly and personnel data should be computerized in order to avoid subjective promotions. ${ }^{123}$ The fact that Suwarno had a strong Islamic orientation indicated that the concern was shared by officers on both sides of the cleavage defined along religious lines; the more significant division in this issue was the one separating officers close to the Presidential Palace from those who were not.124 Finally, the army seminar of 1996 should be noted. It was held on June 18-19-a day before the Medan Congress of the PDI-to prepare for the army's final input to a GBHN 1998-2003.125

"meet the purpose of the journal" - that purpose being, no doubt, indoctrination. Considering these factors, it is understandable that prospective contributors to these journals judge the boundaries that will determine whether or not their articles are accepted-their chances must fluctuate with the civil-military relations of the time-and determine how they will balance between "mask" and "heart," or how they will infuse the latter into the former.

122 Mayjen Hari Sabarno, Reaktualisasi Fungsi Sosial Politik ABRI Dalam Perspektif Indonesia 2020 (Jakarta: Kertas Karya Perorangan [Taskap] Kursus Singkat Angkatan V Tahun 1995, Lemhannas, 1995), p. 71. The summary version of this 82-page thesis was soon published in a Lemhannas journal, but the above reference to Golkar could not be seen here, indicating that he perceived it was not following ABRI's krama. Interestingly, Hari's concern for neutrality was expressed in 1995 when Feisal was preparing to back Golkar and Syarwan Hamid openly stated that ABRI could not be neutral. Although it was extremely rare for an officer not to follow an order from above, limited space for individual thinking made it possible to produce an internal communication arguing the negative impact of policies adopted by the military leadership. Hari was replaced by Syarwan Hamid as Assospol Kassospol in March 1995 and joined the Lemhannas course. After the course, he moved to be deputy head of F-ABRI, then became the head of F$A B R I$, and, under the Habibie government, he got the post of deputy chairman of DPR/MPR.

123 Mayjen Suwarno Adiwidjoyo, "Pemandu Bakat Kepemimpinan Perwira TNI-AD Yang Handal di Era Globalisasi," Yudhagama 59 (July 1996): 61. He was later replaced by Maj. Gen. Budi Harsono after serving eight months as Assospol Kassospol. After the fall of Suharto, the retired Suwarno joined the party executive of PAN (Partai Amanat Nasional-National Mandate Party), headed by Dr. Amien Rais, a popular Muslim opposition leader.

124 An interesting remark was made by Feisal Tanjung in August 1998 when he said that during his term as ABRI Commander, no one-not even he himself, a four-star general-could freely visit the Kopassus sites controlled by Prabowo, a major general. See "Feisal: Saya Tidak Terlibat Kasus Penculikan Para Aktivis," Media Indonesia, July 25, 1998. This showed how ABRI's command structure had been distorted by special preference Suharto gave his son-in-law.

125 GBHN is the Broad Outlines of the Nation's Direction, in which the new Cabinet produce every five years. The seminar was held in Seskoad, and its Steering Team was headed by Brig. Gen. Bambang Yudhoyono (Chief of Staff, Kodam Jaya) while the discussion team was led by Brig. Gen. Agus Wirahadikusumah (Deputy Assistant for General Planning-Waasrenum Pangab). Both were widely respected as intellectuals in uniform. Wirahadikusumah, a classmate of Bambang, is a son-in-law of former vice-president Umar Wirahadikusumah, and the first officer who received the degree of Master of 
The seminar criticized the state apparatus generally as inconsistent in policies, lacking discipline, corrupted, feudalistic, egoistic, and contaminated by nepotism. ${ }^{126}$ The seminar also criticized the intervention of the executive branch in problems having to do with the nation's political infrastructure- made up in part by sociopolitical organizations-and called on the former to reduce its dominance through opendemocratic communication. ${ }^{127}$ Along the same lines, the seminar stated that the recent governmental interventions in Golkar and political parties had been too overt, and suggested that the government use more opaque methods (jangan terlalu transparan)if it really had to (terpaksa) intervene-in order to avoid stirring up negative social reactions. 128 One of the seminar participants described these statements as "an expression of concern among future-looking officers." 129

These suggestions, which issued from the final army seminar to be held under the Suharto polity, were, however, soon buried by the government's and army's repressive efforts to oust the popular pro-Megawati forces from the formal political arena before the elections of 1997. Among those who were involved in the Seskoad seminar, such behavior-which ignored concerns expressed in the seminar papers-was perceived as undermining ABRI's long-term corporate interests. ${ }^{130}$ Revisionist views within the military were further strengthened during the next two years until Suharto's last day on May 21 in 1998. Disenchanted officers were motivated to be "reformists" either by: (1) their deepening concern about the eroding credibility of the military in society; or (2) their power struggle with rival officers placed in Suharto's patrimonial structure. Or by both these considerations. ${ }^{131}$

Public Administration from Harvard University. After the transition of ABRI leadership from Feisal to Wiranto in March 1998, both have played key roles in formulating ABRI's internal reform plans.

${ }^{126}$ Quotations are from seminar documents. Perspektif Pembangunan dan Pengembangan Bidang Politik pada Pelita VII (Hasil Seminar TNI-AD, Bandung, 18-19 Juli 1996), pp. 50-52. Suplemen Substansi Materi Dalam Perspektif Pembangunan dan Pengembangan Bidang Politik pada Pelita VII (Hasil Seminar TNI-AD, Bandung, 18-19 Juli 1996), p.38.

127 Perspektif Pembangunan dan Pengembangan Bidang Politik pada Pelita VII, p. 18.

128 Suplemen Substansi Materi Dalam Perspektif Pembangunan dan Pengembangan Bidang Politik pada Pelita VII, p. 11. If we consider the timing of the PDI Congress in Medan, we might conclude that the seminar's assessment reflected concerns about the way the government-and implicitly the ABRI leadershiphandled the Megawati case.

129 Interview with a brigadier general, October 1996.

${ }^{130}$ For example at Seskoad, which studies ABRI's long-term political strategy, a teaching staff (colonel) asserted that today's Kassospol did not represent ABRI's institutional interests since he was preoccupied with the political game. Personal communication, October 1996.

131 For convenience, I use the term "reformists" to refer to the officers who were concerned about the direction being taken by the military leadership at that time. However, their views were not necessarily synchronized with the reform visions of civilian democratic activists, especially for officers who were preoccupied with internal power struggles with Suharto favorites. Although the boundary between the first and second motives that prompted officers to support military reform was not perfectly clear, since these motives often overlapped, the distinction should not be ignored because it would be reflected in the officers' different attitudes toward social demands for political reformasi (reform) under the Habibie government. 
116 Jun Honna

\section{World View, Domestic Threat Perceptions and Self-Role Beliefs}

It is not surprising that the friction within the military, perceived distortions in Suharto-ABRI relations, and the escalating social criticism of ABRI have all contributed to the erosion of ideological projects led by the Feisal-Hartono leadership. Before we look at the transition to the Wiranto leadership and the fall of Suharto, let us examine this point and assess the diffusion of ABRI's ideological orientation in the late New Order. This is necessary to clarify the changes in and continuity of military thinking during the transition to the post-Suharto regime. The kewaspadaan doctrine applied since the early 1990s mainly consisted of three components-i.e. the defined world view, the defined domestic threat, and the military's perception of its role-and they were linked to construct a discursive technique for neutralizing democratic pressures. We summarize the structure of this hardline approach first, and then look at two other approaches developed within the military.

Democratic activists trying to promote civil society in the country's everyday politics made use of the globalization concept to support their contention that the regime should become more open following the end of the Cold War and the thirty years of New Order authoritarianism. However, ABRI's hardline ideologues, using the same concept of "globalization," found an opportunity to expand the category of "political enemy" to include elements not covered in their traditional catalogue of national threats. As the issue of democratization had constantly forced ABRI to take a defensive posture in political society, the redefinitions of "threats" allowed the military leadership to re-assert itself and tighten its social surveillance policy.

The adaptation of Balatkom language and the kewaspadaan ideological project were meant to help maintain the kind of discursive political power ABRI had enjoyed since the mid-1960s. We examined the way in which the Balatkom campaign developed to neutralize new political phenomena-such as democratization and human rights-by proposing that globalization encouraged the influx of dangerous ideas from abroad. In the advanced stages of this campaign, not only the international environment but problems in government too were utilized in order to expand the sphere of kewaspadaan. Now, the widening socioeconomic gap, government corruption, religious disharmony, industrial disputes, and the decline of society's trust in ABRI were all defined as "opportunities" that invited dangerous communist activities into Indonesia, rather than being defined as problems in themselves. The OTB approach taken by the hardliners implied that those who raised such issues could become campaign targets, and their possible conduct of demonstrations could be interpreted as agitprop, now identified as a communist method. In this framework of assessment, proving a person's communist ideology was no longer necessary. This separation of method and ideology was necessary for the hardliners to reshape the discourse on the communist threat-which was a legacy of 1965-in the face of growing democratic pressure and a widening critical base.

This process resonated perfectly with the self-image of current military officers who believed that their political mission should be oriented in accord with professional military concerns. As seen earlier, Hartono insisted that anticipating, preventing and-if necessary-suppressing the negative impact of foreign-value 
infiltration were the proper tasks of "professional" officers. ${ }^{132}$ It was against this background that ABRI's search for "pihak tertentu" (certain parties) could provide the operational guidance for territorial commands to mobilize the entire technology of their profession to combat the invisible threats and target them. Brig. Gen. Sjafrie Sjamsoeddin argued that:

ABRI's commitment to the defense of national unity based on Pancasila and the Constitution is to be actualized through the preventive strategy [strategi penangkal] which employs the methods of early detection and deterrence. They are to encompass all individuals in this country as our informants. [I]n terms of norms and policy, such a system is well established, though it is not yet perfect at the operational level. ${ }^{133}$

The established strategi penangkal had allowed the territorial apparatus to conduct intelligence operations that targeted students and activists as "informants" in order to identify invisible or latent subversives. ${ }^{134}$ The strategy exemplified how professional officers utilized military techniques and knowledge in the implementation of political missions, although this practice risked rousing public criticism when flawed operations led to illegal activities, such as abduction and the disappearance of citizens. ${ }^{135}$

132 It should, however, be noted that many of the elite officers had been trained in the US, and so had benefited from foreign ideas.

133 Written interview with Brig. Gen. Sjafrie Sjamsoeddin, Chief of Staff of Kodam Jaya, December 23, 1996. Sjafrie was then promoted to become Commander of Kodam Jaya in September 1997, but was transferred to the less influential post of Assistant of Territorial Affairs to the ABRI Commander in June 1998, probably to take responsibility for the May 13-15 riots in Jakarta; the new Pangab, Gen. Wiranto, in August 1998, admitted military elements had been involved in the riots. However, it was commonly suspected that the riots were indeed engineered by the key army officers around Prabowo, including Syafrie himself. See, for example, "Teka-Teki Jenderal Sjafrie," Tajuk, September 1-3, 1998.

134 About the practice of on-campus intelligence activities, see Human Rights Watch, "Academic Freedom in Indonesia: Dismantling Suharto-Era Barriers" (New York: Human Rights Watch, 1998), Chapter 9. The idea that "the people" consists entirely of "informants"-i.e. people who give information about the others-comes straight out of the occupation of East Timor where kidnappings, executions, and acts of torture were commonplace. These East Timor practices seeped into Indonesia in the 1990s.

135 The Kopassus Commander, Maj. Gen. Prabowo, was promoted to the Kostrad Command with threestar rank, just after the presidential re-election of Suharto-with Habibie's promotion to vice-president-at the MPR's general session in March 1998. In conducting security operations to "prevent instability" at this MPR event, Prabowo and his aides in Kopassus, since February 1998, conducted abductions of student activists who had staged anti-Suharto demonstrations. Most of them were Megawati supporters and PRD activists. Under the Habibie government, which was formed on May 21, Gen. Wiranto ordered an investigation and Prabowo admitted in front of the Officers' Honor Council (DKP)-held in August-his involvement in the abduction of nine activists who had already been released. The DKP discharged Prabowo from the military organization. However, there are still many who are missing, at least fourteen as reported, and Sjafrie's involvement was also suspected. See, for details, "Melilah-Milah Komando Penculikan," Tajuk, September 1-3, 1998. Kopassus had received professional military training from the US and Australia. Even after the official 1992 ban on US training of Indonesian military men-a result of the Dili incident-more than twenty instances of US training had been reported, the latest one conducted just before the 1998 MPR. These courses of training were said to have specialized in torture, disappearance, urban combat techniques, psychological warfare, and night raids on civilian homes-all sugar-coated with the term "counter-terrorism." For details, see "U.S. Aids Killers in Indonesia," Sacramento Bee, March 29, 1998 and "Jakarta Opposition Leader Decries US Role in Troop Training," Chicago Tribune, March 25, 1998. More details are described in Allan Nairn, Our Kind of Guys: The United States and the Indonesian 
118 Jun Honna

In legitimizing the search for Balatkom and invisible subversives, the reformulation of ABRI's world-view was key. The ideology of kewaspadaan now targeted global change, bringing "globalization" into its perceptual scope, and identified it as a source of domestic instability after the fall of the Communist Second World. This broad paradigm, however, provided only a very vague definition of how the alien elements would take root domestically and who would be the principal sponsors. A space for arbitrary interpretation existed here, providing a license for the hardliners to label their own political enemies as national security threats. The ideological fortification of kewaspadaan via this approach was prompted by the desire to control the pace and degree of political change. Moreover, the military's frequent call for Islamic solidarity was a tactical measure used to blur the conflict between preservation of the regime and social demands for democratic liberalization. Marzuki Darusman recognized that: "the bahaya [hazard] campaign is an attempt to slow down the speed of keterbukaan, and it is not really bahaya for the right, left, and others, but bahaya for the change itself. They [ABRI and that government] cannot say that they do not want the change, thus they use the bahaya language to protect themselves from the change." 136 It is in this context that we may conclude that these political orientations constituted the core aspect of kewaspadaan doctrine applied by military hardliners during the late Suharto era.

Among ABRI circles, however, less dogmatic responses to global change as it links to domestic threat have also been developed, with resulting differences in the perceived role of $A B R I$. One set of views emphasizes the emergence of political threats resulting from globalization and insists on the need for ABRI to expand the scope of its political control. However, Balatkom connotations were not built into this discourse. Maj. Gen. Budi Harsono, for example, explained that:

[T]he gap between the OKB (orang kaya baru: the new rich) and the OMB (orang miskin baru: the new poor) in big cities is becoming serious. The OMB are far poorer than the people in the village.... and globalization encourages this phenomenon. ABRI needs to carefully watch out for this tendency and promote professionalism in order to overcome such an impact of globalization. ${ }^{137}$

Another intellectual officer, Col. Syarifudin Tippe, also saw a new challenge in the global and domestic political arena and described ABRI's increasingly important role as democratizer. He wrote:

Globalization ... facilitates the linkage between democratization in foreign countries and the demands for political opening (keterbukaan) in our society. One obvious dimension [of this phenomenon] is the increase in accusations against the military's dominant role. This happens everywhere in the world, including Indonesia. Coupled with the wave of democratization, demands for improving

Military (New York: Verso, 1999). It is easy to suspect that such training contributed to the professionalization of army-implemented disappearance and abduction.

136 Interview with Marzuki Darusman, Deputy Chair of Komnas HAM, March 27, 1997.

137 Interview, January 31, 1997. Maj. Gen. Budi Harsono was Assospol Kassospol at that time, serving the hardline Syarwan Hamid. He was replaced by Maj. Gen. Bambang Yudhoyono in July 1997 and posted to F-ABRI. Bambang's entry to ABRI's sociopolitical section might reflect the willingness of Gen. Wirantowho had replaced Hartono as Army Chief in June 1997, after the general election-to consolidate his power base with reform-minded intellectual officers who differed from the hardline group surrounding Prabowo. 
human rights and civil rights in politics have become stronger. All these demands ask ABRI to share power with other [non-ABRI] parties... and to play the demokratisator (democratizer) role. ${ }^{138}$

Absorbing social demands, rather than rejecting them, and transforming ABRI into a democratizing force are Tippe's answers to dilemmas created by the political impact of globalization. But democracy here, in the common ABRI language, is a democracy based on Pancasila-the state ideology of anti-liberalism. ABRI's proposed responsibility as the promoter of democracy, therefore, does not necessarily reduce its role in politics. In this context the ideas presented by Budi Harsono and Syarifudin Tippe are revealed to have the same orientation, for these men too would argue that ABRI should play an active role in confronting problems created by globalization. Their emphasis was slightly different from the hardline approach that employed its distorted world view to assert the resurgence of the old threat-communism-in order to justify the military repression of popular movements. This second type of approach, which does not use dogmatism but still conforms with ABRI's traditional paternalistic self-image, can be categorized as the moderate school of thought. ${ }^{139}$

In $A B R I$ circles, however, there was still also another set of views. Officers in this camp noted that the social space ABRI required to carry out its political role was shrinking. The view that the nature of the threat was changing in a way that necessarily reduced the role of the military was expressed, for example, by Maj. Gen. (ret) Maulani, who argued as follows:

In the past, until the 1980s, the threat was dominated by ideological conflicts, physical insurgencies, and political party conflicts. . . Reflecting these, ABRI's management of stability was oriented by political and military approaches. However, the current threat is colored by the economic gap between the rich and poor and social injustice as represented by land disputes. It is globalization which has brought these issues to the surface. In order to respond to these threats to stability, ABRI's previous politico-military approaches are useless. What is required is the improvement of distributive economic policy and a strong judicial system to implement consistent and impartial decisions, which result in a reduced role for ABRI and broader participation of social sectors. ${ }^{140}$

138 Syarifudin Tippe, Peran Sosial Politik ABRI Dalam Meningkatkan Kualitas Pengamalan Wawasan Kebangsaan di Tengah kecenderungan "Global Paradox" (Narasi) (Bandung: Forum Pengkajian Seskoad, Orasi Ilmiah Pada Ulang Tahun Seskoad Ke-44, 25 May 1995), p. 6. Tippe at that time served Gen. Feisal Tanjung as Personal Staff Coordinator for the ABRI Commander, and was also a devout Muslim. Reflecting the anti-Murdani posture of many ICMI-linked officers, this Feisal follower (graduate of Akabri in 1975) criticized the old intelligence policy of the 1980s which compelled officers to obtain ABRI permission before publishing any statement in the mass media. Tippe argued that this restriction had killed the officer's intellectual creativity. See his interview in "Syarifudin Tippe: Banyak Perwira yang Pinter," Forum Keadilan, July 3, 1995.

${ }^{139}$ Here I do not mean to attribute the idea to the individual officer and judge his entire political views based on the proposed category. Rather, the classification is intended to assess systematically the existing perceptions within ABRI. Thus, it is not a problem if an officer expresses different opinions on different occasions.

140 Interview with Maj. Gen. (ret) Zein Maulani, Adviser for Military Affairs for B. J. Habibie, Minister of Research and Technology, November 28, 1996. Maulani became Chief of Staff of the Vice-Presidential Office when Habibie was elected as vice president in March 1998, and, in September, was appointed as the 
120 Jun Honna

A similar opinion was expressed by a serving two-star general who emphasized the multi-dimensional impact of globalization and insisted on the need for a rational division of labor, arguing that:

[T] he current wave of globalization pushes social values in one [universal] direction ... and Indonesia is not an exception. This invites the question of the military's place in a modern society. ... ABRI should not believe that it can solve all problems. That would be counter-productive. Rather, non-ABRI sectors should be empowered and, in this process, the political center will move to the Interior Ministry [from ABRI], while security matters, especially in the big cities like Jakarta, should be handled by the Police. Thus, ABRI has to change its way of thinking . . . but the problem now is: who wants to lose the power? Still there are many conservatives within ABRI. ${ }^{141}$

These two ideas define the nature of the threat and the role of ABRI in relation to societal change. Their emphases differ, as Maulani sees the main threat shifting from politics to economics, while the active-duty officer above insists on the convergence of global values. However they both minimize the need to defend the country from globalization and also recognize the necessity to decrease the role of the army in confronting global-domestic pressures for change. In the triple interaction between world view, domestic threat, and ABRI's beliefs about its own role, these ideas constitute a progressive approach that emerged during the late New Order period.

The growing diffusion of ideological orientation among officers was, in this way, reflected in their different perceptions about ABRI's future prospects. The first approach-the hardliner doctrine-was, to a large extent, the product of Suharto's political interests; he needed to convert the military leadership from the Murdani-Try approach to the more amenable Feisal-Hartono approach in order to secure his political succession in 1998. As discussed above, the two leaderships were antagonistic to one another, but in the formulation of counter-democracy discourse under Feisal's $\mathrm{ABRI}$, the established framework of kewaspadaan thinking that had been constructed during the Murdani period contributed significantly, even though the two versions would not be applied in the same way. But the ideological cohesion of Feisal's ABRI had been eroded within the officer corps, as implementation of its policies became dogmatic and threatened to damage social trust in ABRI, while the new military leadership had demoralized members of the military itself, who were disheartened by nepotistic and politicized personnel transfers. If this is true, then our discussion suggests that there may be a shift in ABRI's ideological orientation toward approaches described above as "moderate" and "progressive" after the fall of Suharto. It is still too early to determine whether this kind of evolution will take place, as the transition of the regime in the post-Suharto era is not yet completed, and thus the new civil-military relationship has not yet been structured. But the fall of Suharto certainly raised issues that illuminate future, potential prospects.

head of BAKIN - a body directly responsible to President Habibie. His willingness to assign ABRI a lesser role in politics may reflect his support for the civilian Habibie.

141 Confidential interview, January 1997. The term "conservatives" here may be identical to "hardliners." 


\section{Ideological Repositioning and the Institutional Legacy of the Kewaspadaan Mind- set}

The transfer of military leadership took place when Army Chief Gen. Wiranto was appointed as the Pangab in the end of February 1998. Gen. Wiranto was welcomed by those who had been concerned about the political ambitions of Prabowo, backed by Suharto; though he had served as a former Presidential adjutant (1988-93), Wiranto was regarded as a more professionally oriented officer and accepted by many as a man to support. ${ }^{142}$ Feisal Tanjung was transferred to the post of the Coordinating Minister for Political and Security Affairs, but he played a watchdog role in insuring that the March MPR session endorsed Suharto and Habibie as president and vice-president for the next five years. ${ }^{143}$ Post-presidential election Indonesia was, however, preoccupied with the escalation of student demonstrations demanding that Suharto resign to help solve the economic crisis. Interestingly, the new ABRI leadership-under Wiranto (who was also appointed as Defense Minister in the new Cabinet) with the support of new Army Chief, Gen. Soebagyo, and new Kassospol, Lt. Gen. Bambang Yudhoyonoshowed a "responsive" and sympathetic attitude toward the anti-Suharto movements in society, offering several occasions for dialogue rather than Balatkom propaganda. ${ }^{144}$

142 Wiranto was a graduate of the military academy in 1968, and he served as the Commander of Kodam Jaya (Jakarta) during 1994-96, the Kostrad Commander during April 1996-June 1997, and as the Army Chief after Hartono. Bambang Yudhoyono was his main supporter in the intra-military struggle with the Prabowo circle. Suharto, the master of "devide-and-rule" strategy, let their competition go on in order to create the power balance which would make both sides rely on him.

143 It was Feisal, Prabowo, and Sjafrie who together helped destroy the candidacy of the incumbent vice president Try Sutrisno. Try's renomination was suggested by CSIS, a think-tank led by Chinese Indonesians (many of whom were Catholics), where the retired Murdani was also associated. Amidst the deepening economic crisis, which hit the country in mid-1997, Feisal, still as Pangab, attacked Sofyan Wanandi-a businessmen who sat on the Board of CSIS-by claiming that Sofyan was not interested in helping the government solve the national crisis because he refused to join the voluntary donation movement proposed by Feisal. Further pressure came from Sjafrie when Kodam Jaya "accidentally" found an alleged PRD document following a bomb blast in the apartment of a young radical activist. The document-an e-mail message-stated that Sofyan had offered financial support to the group's activities. Sjafrie's command interrogated Sofyan and recommended calling in other CSIS associates, which in turn led to speculation that Murdani would also be questioned. Sjafrie denied it but Sofyan's interrogation led to a series of radical Muslim youth demonstrations in front of CSIS, demanding the dissolution of the think-tank. The demonstration was led by a radical Muslim group, KISDI (the Indonesian Committee for World Muslims), which had close links with Prabowo. Before this event, Prabowo broke the Muslim Ramadan fast at his Kopassus headquarters in the company of about five thousand guests, including many representing radical Islamic groups, and warned them that a political conspiracy organized by certain groups was behind the current economic crisis. He distributed a list of Chinese-owned Asian business groups and asked these Muslims to fight with ABRI against this conspiracy. For details, see "Soal Permainan Politik di Balik Krisis Rupiah Mereka Pengkhianat," Republika, January 24, 1998; "Us' and 'Them:' Muslim Activists Say Its Time to Seize Economic Power," Far Eastern Economic Review, February 12, 1998. Such developments were enough to bury the possible emergence of a call to renominate Try Sutrisno.

144 As seen earlier, Soebagyo had been regarded as a friend of Prabowo, but apparently he did not move to disrupt Wiranto's consolidation of power, perhaps because the Army Chief had no troops under his direct command, or because his respect for organizational discipline outweighed the personal tie to Prabowo. Confronted by escalating student demonstrations, the Wiranto circle responded by initiating dialogues with social figures. Four days before Suharto's resignation, for example, Bambang Yudhoyono was invited to the Salemba campus of the University of Indonesia, where he had a dialogue with several critical retired officers, academics, and religious leaders. They adopted the "Salemba Declaration" calling 
The escalating street demonstrations led by students finally resulted in Suharto's resignation and announcement that he would hand over his presidency to Habibie on May 21. It was six days from the Jakarta riot which terrified the country and highlighted the peak of Prabowo's prominence. ${ }^{145}$

The political reform campaign that followed the collapse of the Suharto regime inevitably found a target in ABRI. The military's past human rights abuses-including abduction of political activists which went back to the July 27 riot in 1996-were openly discussed and its withdrawal from politics widely demanded. In the first few months since Suharto's departure, Wiranto's response to these pressures was generally accommodating. The new military leadership decided to withdraw some troops from East Timor, Irian Jaya, and Aceh, all regions where ABRI had previously conducted intense security missions by imposing on them the status of Military Operation Area (DOM), a designation that freed the army to crush separatist rebellions. ${ }^{146}$ In Aceh, past accounts of military repression were widely publicized by the NGOs and the media-newly "empowered" by Habibie's ending of press censorship in late Maywhen a number of mass graves of the victims were identified. Every day, new horrors in these regions were exposed by the media. Facing such a public mood, Wiranto publicly apologized to the people in Aceh-this was the first time in Indonesian history that a general had offered such an apology-and he abolished the status of DOM in August. However, the apology was not enough to halt the acceleration of separatist movements in these regions. Continuing resistance was evidence of the New Order's failure to integrate the nation through military repression, which had intensified since the late 1980 s. Wiranto also accepted the idea to reduce the number of ABRI's appointed seats in the DPR from 75 to 55, while at the same time deciding to separate the Police from the military structure. "Reformist" officers like Bambang Yudhoyono openly admitted that ABRI had made many errors in the past and would reduce its political involvement in the current era of political reform.

for Suharto to step down. Bambang said that the meeting expressed the people's aspirations, and he characterized the demand for Suharto's ouster as an expression of their love for the nation, a demand which should be heard by ABRI and the government. See "Jenderal Purnawirawan dan Guru Besar ke DPR, Mendesak Segera Digelar Sidang Istimewa," Jawa Pos, May 18, 1998.

145 It was five months after the riot that the government-established Joint Fact-Finding Team (TGPF) for the May riot submitted its final report. The Team was formed in July and consisted of military officers, bureaucrats, lawyers, and NGO activists under the leadership of Marzuki Darusman. The estimated death toll during the riots of May 13-15 ranged from 400 to 1,200 and the Team avoided to provide its own account. The report however recommended the government to court-martial Prabowo in charge of abductions and investigate his and Sjafrie's roles in provoking the riots. See Laparan Akhir Tim Gabungan Pencari Fakta Peristiwa Tinggal 13-15 Mei 1998 [Ringkasan Eksekutif] (Jakarta: Tim Gagungan Pencari Fakta, 23 October 1998), chapters IV.3.2 and VII.2. Prabowo himself denied the accusation and claimed that every military operation in Jakarta was under Sjafrie's responsibility. But many observers believe that the Prabowo circle-bypassing Wiranto-attempted to make the ground for the reimposition of Martial Law by provoking the riots not only in Jakarta but also in other areas such as Medan and Solo, which in turn would have reinstituted Kopkamtib with Prabowo as its commander. This would have put him effectively above Wiranto. As Marzuki Darusman explained, these riots were all very similar in method and style. "Marzuki Darusman, Ketua TGPF: Persepsi Para Perwira Itu Berlainan," Tajuk, October 15, 1998.

146 Withdrawal of one thousand troops from East Timor was announced in August. But it was later suspected that ABRI had covertly increased the forces in East Timor during 1998. 
We must consider this chain of developments, including, notably, the end to press censorship, when assessing the direction of ABRI's ideological shift under the new military leadership. In the previous section, we attempted to identify ABRI's ideological orientation based on three components-namely world-view, domestic threat perception, and its definition of its own role-and posited three types of doctrinal approaches-hardline, moderate, progressive. The military leadership during the first three months of the Habibie government seemed to have been oriented to the second "moderate" approach, which recognized the need for adjusting ABRI's role in order to guide the regime's transition in the changing domestic and international environment. This perception was strongly reflected in the first reform proposal formulated by ABRI's reform team led by the Kassospol, Bambang Yudhoyono. The team submitted a proposal to Habibie outlining ABRI's basic ideas about the direction of political reforms. Among other things, the report insisted on ABRI's commitment to democratic reforms and responsibility for protecting citizens' human rights, a significant declaration, since "human rights" had been represented by hardliners as a dangerous foreign concept. The report called for Indonesia's ratification of international human rights conventions, including the Vienna Declaration and Program of Action adopted by the UN World Conference on Human Rights in June 1993. ${ }^{147}$

The third "progressive" approach is also discernible. One of Wiranto's advisors, Lt. Gen. Agus Widjojo, had written in 1992: “. . . ABRI's ideology has to be guided by rational, open and discussable methods rather than dogmatic indoctrination." Moreover, regarding dwifungsi, he insisted that "we should be brave enough to decide the priority between defense and political roles, because ABRI does not have enough time to produce personnel who are competent for the two roles simultaneously."148 ABRI's priority, of course, should be in the defense field. Evidence that Widjojo's "progressive" attitude has influenced events can be seen in the decision to separate the Police from ABRI, a measure which Widjojo himself handled in his role as Assistant for General Planning. Here, ABRI's gradual retreat from non-military fields is explained among officers as an inevitable consequence of domestic and global changes, an analysis that accords with the third approach. In line with this, Bambang Yudhoyono insisted at an ABRI seminar-held in September 1998-that he would even support the idea of liquidating ABRI's sociopolitical section if the people believed its function was

147 ABRI dan Reformasi: Pokok-Pokok Pikiran ABRI Tentang Reformasi Menuju Pencapaian Cita-Cita Nasional (Jakarta: Mabes ABRI, June 1998), p. 21. The Vienna Declaration and Program of Action, for example, declared that "the promotion and protection of human rights and fundamental freedoms at the national and international levels should be universal and conducted without conditions attached" (Article 8). Accepting this clause requires ABRI to abandon its long-standing cultural relativism in the human rights debate.

148 Col. Agus Widjojo, “Upaya Peningkatan Kualitas Personil ABRI Sejalan Dengan Upaya Peningkatan Kualitas Sumber Daya Manusia," Widya Dharma (Majalah Sesko ABRI) 18 (1992): 71, 85. This article was originally written during his training at Sesko ABRI and was selected as the best working paper in its regular course of 1991-1992. Widjojo, a graduate of Akabri in 1970, is regarded as one of key intellectual officers-together with Bambang Yudhoyono and Agus Wirahadikusumah-helping Wiranto shape ABRI's new paradigm. He is a son of Maj. Gen. Sutojo, who was one of six generals killed in the abortive coup of September 30,1965, and a holder of Master's degrees from Georgetown and Manchester Universities. Under the Wiranto leadership, he served as Assistant for General Planning (Asrenum Pangab) until January 1999, then became the Commander of Sesko ABRI. 
irrelevant. ${ }^{149}$ The progressive approach is inclined to recommend that officers consider and take into account significant societal and global contexts when evaluating ABRI's proper role in national life, whereas the moderate mode of thinking primarily seeks a space in political life to project ABRI's established paternalistic role and retain initiative in the political process.

Under Wiranto, however, a new ideological color for ABRI was not institutionally established. A day after the ABRI seminar in September, the Balatkom language reemerged in ABRI's political discourse. The escalating student demonstrations, which now demanded Habibie's resignation and the removal of dwifungsi, finally pushed the new president to instruct ABRI to take severe actions to stop street activities which could endanger the government. Following these instructions, Wiranto made a kewaspadaan-type public statement in which he said that the "style" of recent demonstrations resembled that of the communists, and he identified the Forkot (Forum Kota, or City Forum), an organization consisted of students from thirty-seven universities, as communist oriented. ${ }^{150}$ Not only in Jakarta, but in West Java, East Java, and Sumatra, student groups were suddenly labeled as left-wing elements which should be kept under observation. ${ }^{151}$ Wiranto's initiation of a ghost-hunting campaign reasserted the Balatkom doctrine developed by the Feisal-led ABRI in the mid-1990s. Thanks largely to the efforts of Hartono, Syarwan, and Soeyono, Wiranto was able to rely on the technique to label popular movements as communist, claiming that they had used agitprop - or other communist-type methods-in conducting demonstrations. His initiative undermined the Bandung Seminar's proposal that all dogmatic doctrines and operations should be eliminated from ABRI. ${ }^{152}$ It is in this context that the continuity of ABRI's ideological orientation should be considered.

In the late New Order state, Suharto was the center of political power and the military leadership was formed by officers loyal to him. The development of a hardline approach could not be separated from this political context. Under Habibie, state power seemed to have no single center, and the military leadership was not recruited primarily based on their loyalty to the new president. However, two legacies were inherited by the post-Suharto regime. The first was the structural nature of the President-military relationship, and the second was the New Order military's traditional, dwifungsi characterization of its own role in the nation. As discussed in the previous section, "reform-minded" officers were concerned about the subordination of

149 "Berubah Sebelum Ditinggalkan Sejarah," Tajuk, October 1, 1998. This seminar, held in Sesko ABRI (September 22-24), produced the second official paper-following the June paper prepared by the Bambang team-concerning the future political role of ABRI. But the liquidation of ABRI's sociopolitical section was Bambang's own idea, as it was not mentioned in the seminar paper-Peran ABRI Abad XXI: Redefinisi, Reposisi dan Reaktualisasi Peran ABRI dalam Kehidupan Bangsa [Makalah Awal Seminar ABRI] (Bandung: Sesko ABRI, September 1998). In November, the idea was officially adopted and the sociopolitical section was replaced by the territorial section. That this reorganization actually reduced ABRI's political commitment was, however, doubtful, as ABRI's territorial operation was essentially aimed at maintaining political stability.

150 "ABRI Waspadai Gerakan 30-S Forkot," Republika, September 25, 1998. Emphasis added. Forkot had been one of the most active groups demanding Habibie's resignation, the establishment of a transitional government led by a presidium, and the elimination of dwifungsi.

151 For a discussion of the campaign, see "Hantu' PKI di Era Reformasi," Tajuk, October 1, 1998.

152 Peran ABRI Abad XXI, p.30. 
the military institution to the political interests of Suharto and the military's consequent loss of public trust. It was against this background that the need for limiting the power of the president and rejuvenating ABRI's autonomy in political life was demanded by key officers in the Wiranto circle. ${ }^{153}$ The president of Indonesia, as ABRI's Supreme Commander, is tempted to "order" the Pangab to provide support in conducting his political projects. In the post-Suharto civil-military relations, this structural legacy remained untouched, and Wiranto's adoption of the hardline approach was, to some extent, a reflection of this. ${ }^{154}$

On the other hand, Wiranto's partial adoption of the Balatkom approach illustrated the durability of the kewaspadaan doctrine which had invariably been invoked under the New Order, regardless of the characteristics of the military leadership. As discussed previously, the core institutional incentive for this doctrine is ABRI's permanent need to reproduce the legitimacy of its role as national guardian, a need which has required ABRI to identify imagined threats to national stability. As it has faced seemingly endless public criticism since the very beginning of the Habibie government, ABRI has found that popular movements have ignored its declared willingness to carry out politico-military reforms gradually. It was not surprising that military figures already began to perceive the escalating anti-military pressure as a serious "threat" to its established self-perception as the defender of the nation. In fact, as ABRI's past human-rights abuses increasingly occupied the country's political debate, Wiranto started to argue that ABRI's in-house reform should not be on the public agenda, and he claimed that "certain groups" were now attempting to discredit ABRI. ${ }^{155}$ The military's perception that civilians who intervene in the military's professional affairs may try to discredit ABRI does not harmonize very well with ABRI's declared commitment to democratization; a reactive, combative, self-defensive discursive legacy apparently still influences civil-military communication. The past experience shows that ABRI's reactive posture can easily lead to the arbitrary labeling of social elements as threats to the nation (not to ABRI). Reflecting this tendency, a two-star general in ABRI's education sector recently insisted on the need for strengthening kewaspadaan against the extreme left, right, and others, threats which were all visible now. As a response to these threats, he argued, the Tarpadnas project needed to be upgraded. ${ }^{156}$

153 This point was reflected in the assessment of the Bambang team in June. See ABRI dan Reformasi, pp. 13,15 . Also at the Bandung Seminar in September, Widjojo argued that during the Suharto era the President expanded the role of the military in order to use it for his own interests. Mayjen TNI Agus Widjojo, "Peran ABRI pada Abad XXI: Redefinisi, Reposisi dan Reaktualisasi Peran ABRI dalam Kehidupan Bangsa dengan Obyek Bahasan pada Paradigma Baru," working paper presented at Seminar ABRI tentang Peran ABRI Abad XXI, Bandung, Sesko ABRI, September 23, 1998, p.5.

154 Two major-generals close to Wiranto both insisted that Wiranto's gradual subordination to Habibie and his reluctance to say "no" had resulted in the postponement of ABRI's implementation of its internal reform programs. Interviews, October 1998. Harold Crouch also argues that Wiranto's personal support within ABRI was not sufficient to prevent Habibie appointing another senior officer in his place. Habibie could replace Wiranto anytime but not vice versa. See Harold Crouch, "Wiranto and Habibie: MilitaryCivilian Relations since May 1998," paper presented at the conference, entitled "Democracy in Indonesia?: The Crisis and Beyond," Monash and Melbourne Universities, December 11-12, 1998, p.8.

155 "ABRI's Internal Affairs 'Are Not Public Issue," Jakarta Post, September 5, 1998 and "Wiranto Tak Setuju Nama Kopassus Diganti," Jawa Pos, September 5, 1998.

${ }^{156}$ Interview, October 1998. 


\section{Jun Honna}

The kewaspadaan mind-set, therefore, reasserts itself in ABRI's institutional efforts to defend its established perception of its own role, which has been threatened by growing popular demands for the elimination of dwifungsi and the military's return-tothe-barracks. ${ }^{157}$ From this perspective, the manipulation of world-view-involving the evocation of concepts like globalization-continues to provide an opportunity for ABRI to interpret these demands as dangerous "foreign" ideologies which should be extirpated either through strategi penangkal or repressive security operations. It is in this context that, in the long-run, civilians who want to complete the transition to democracy are required to promote civil-military communication-for example at Lemhannas under the new education policy-to prevent ABRI from easily developing and reasserting its kewaspadaan ideology. Doing so may require the tactical and planned redirection of ABRI's perception of its own role; it is especially important to target and neutralize ABRI's developmentalist ideology which has provided the primary justification for permanent military engagement in non-military fields. The kewaspadaan doctrine will have no space for itself if the army can be freed from this developmentalist ideology, which mandates a constant hunt for the sources of instability in the everyday political arena. An alternative ideology-one that sees political conflict in society as both "necessary and normal" in any healthy political system-should be introduced into officer indoctrination as a long-term project to promote democratic civil-military interactions.

157 I have treated ABRI and the army as if they were equivalent. For most of the New Order, this characterization was reasonable, as the police had been integrated into ABRI, and the navy and air force were suppressed because of Sukarnoist sympathies. But in the current situation, where the separation of police is planned in April 1999 and demands for more organizational autonomy are increasingly apparent within the navy and air force (which contend that the abuses of military power have all been enacted by the army, resulting in the growing unpopulality of $A B R I$ as a whole), it is perhaps no longer appropriate for the army to speak as if it were ABRI. But for the sake of consistency, I continue to use the term "ABRI" to refer to the army through this entire article. 